Canadian Science Publishing

Canadian Journal of Earth Sciences Revue canadienne des sciences de la Terre

\title{
Remnants of Early Mesozoic basalt of the Central Atlantic Magmatic Province (CAMP) on Cape Breton Island, Nova Scotia, Canada
}

\begin{tabular}{|r|l|}
\hline Journal: & Canadian Journal of Earth Sciences \\
\hline Manuscript ID & cjes-2016-0181.R1 \\
\hline Manuscript Type: & Article \\
\hline Date Submitted by the Author: & 07-Nov-2016 \\
\hline Complete List of Authors: & $\begin{array}{l}\text { White, Chris E.; Nova Scotia Department of Natural Resources } \\
\text { Kontak, Daniel J.; Department of Earth Sciences, } \\
\text { Demont, Garth J.; Nova Scotia Department of Natural Resources } \\
\text { Archibald, Douglas; Queens University, Department of Geological Sciences }\end{array}$ \\
\hline Keyword: & CAMP, Mesozoic, Fundy Basin, Ashfield Formation \\
\hline & \multicolumn{2}{l}{} \\
\hline
\end{tabular}

\section{SCHOLARONE \\ Manuscripts}


Remnants of Early Mesozoic basalt of the Central Atlantic Magmatic Province (CAMP) on Cape Breton Island, Nova Scotia, Canada

Chris E. White ${ }^{1}$, Daniel J. Kontak ${ }^{2}$, Garth J. DeMont ${ }^{1}$, and Douglas Archibald ${ }^{3}$ 1. Nova Scotia Department of Natural Resources, Halifax, Nova Scotia, B3J 3T9, Canada 2. Department of Earth Science, Laurentian University, Sudbury, Ontario, P3E 2C6, Canada 3. Department of Geological Sciences and Geological Engineering, Queens University, Kingston, Ontario, K7L 3N6, Canada

Corrected version: for re-submission to CJES

November 7, 2016

\begin{abstract}
Amygdaloidal basaltic flows of the Ashfield Formation were encountered in two drillholes in areas of positive aeromagnetic anomalies in the Carboniferous River Denys Basin in southwestern Cape Breton Island, Nova Scotia. One sample of medium-grained basalt yielded a plateau age of $201.8 \pm 2.0 \mathrm{Ma}$, similar to $\mathrm{U}-\mathrm{Pb}$ and ${ }^{40} \mathrm{Ar} /{ }^{39} \mathrm{Ar}$ crystallization ages from basaltic flows and dykes in the Newark Supergroup. A second sample of zeolite-bearing basalt yielded a discordant age spectrum and a younger age of ca. $190 \mathrm{Ma}$ which is interpreted to date a widespread hydrothermal event related to zeolite formation. Whole-rock chemical data show that the Ashfield Formation basalt is low-Ti continental tholeiite, consistent with its within-plate
\end{abstract}


tectonic setting. It chemically resembles basaltic flows in the Mesozoic Fundy and Grand Manan basins exposed in southern Nova Scotia and eastern New Brunswick, and elsewhere in CAMP. The age and geochemical data from the Ashfield Formation provide the first evidence for early Mesozoic CAMP volcanism in Cape Breton Island, and demonstrate that the event was more widespread than previously thought in Nova Scotia, which has implications for its continuity and extent elsewhere within CAMP.

Key Words: CAMP, Mesozoic, Fundy Basin, Ashfield Formation

\section{INTRODUCTION}

Continental tholeiitic basalt flows, dykes, and sills of the Central Atlantic Magmatic Province (CAMP) were erupted in circum-Atlantic basins in North and South America, Africa, and Europe (Fig. 1) over a total surface area likely exceeding 10 million km² (Marzoli et al. 1999, 2004; McHone et al. 2005; Verati et al. 2007). The basins along the eastern margin of North America from South Carolina to Nova Scotia and Newfoundland contain a nearcontinuous sequence of Late Triassic to Early Jurassic sedimentary and volcanic rocks, and related basaltic dykes that extend over an even larger area (e.g., McHone et al. 1987; McHone 1992, 1996; Blackburn et al. 2013; Merle et al. 2014).

In onshore Maritime Canada (Fig. 2), the early Mesozoic sedimentary and volcanic rocks are termed the Fundy Group (Klein 1962) and occur around the margins of the Bay of Fundy and Minas Basin (Fundy Basin of Wade et al. 1996) and on Grand Manan Island (Grand Manan Basin of McHone 2011). Early Mesozoic rocks of the Fundy Group also occur along the north shore of Chedabucto Bay in northern mainland Nova Scotia (Fig. 2), where they are termed the Chedabucto Formation (Klein 1962; Tanner and Brown 1999; White and Barr 1998, 1999). 
Olsen (1988) informally designated the location of these outcrops to the "Chedabucto Basin", but later workers (e.g., Tanner and Brown 1999, 2003) considered these outcrops as laterally equivalent to those in the offshore Orpheus graben to the east. Olsen (1978) and Sues and Olsen (2015) included all early Mesozoic rocks of eastern North America, including the Fundy Group, in the Newark Supergroup.

During a 1983 drilling program by the Nova Scotia Department of Mines and Energy in the River Denys Basin in search of Cretaceous deposits (MacDougall and Polley 1984), drillhole IM-2 near Iron Mines (Fig. 3) bottomed out in amygdaloidal basalt. Another hole (ASH-01-1) drilled in 2001 at a location $8.3 \mathrm{~km}$ to the south also encountered amygdaloidal basalt (Feetham et al. 2002). Initially the basalt was assumed to be Devonian or Carboniferous and related to the ca. 375-370 Ma Fisset Brook Formation (Dunning et al. 2002) or to ca. 340 Ma Carboniferous basalts at the base of the Windsor Group (Barr et al. 1994). However, in this paper we present evidence, based on ${ }^{40} \mathrm{Ar} /{ }^{39} \mathrm{Ar}$ whole-rock dating and lithogeochemical data, that these subsurface basalt flows, named the Ashfield Formation by White and Boehner (2008), are Mesozoic and related to the Triassic-Jurassic basalt of the Fundy Group and Newark Supergroup. The results are important as they provide further evidence for the contiguous nature of these flows and that their unknown subsurface extent may be substantial, as in the case of the Eastern North American magmatic province to the south (Marzoli et al. 1999, 2004; Hames et al. 2000).

\section{FIELD RELATIONS AND BASALT PETROGRAPHY}

The River Denys Basin (Kelley 1967) is one of several Carboniferous lowlands that lie on the pre-Carboniferous Bras d'Or terrane (Barr and Raeside 1989), part of Ganderia in the northern Appalachian orogen (Hibbard et al. 2006). The basin is flanked to the north and south 
by the Creignish Hills and North Mountain, respectively (Fig. 3); the geology of the area has been presented in Kelly (1967), White and Boehner (2008), and White et al. (2016). These uplands are composed of Proterozoic to upper Devonian metamorphic, plutonic, volcanic, and sedimentary rocks, whereas the low-lying River Denys Basin is underlain primarily by anhydrite and gypsum, interbedded with siltstone and limestone, and is assigned to the middle and upper parts of the Middle to Late Mississippian Windsor Group. Along the margins of the basin, these rocks overlie interbedded siltstone, sandstone, and conglomerate of the Tournaisian Horton Group. To the west and east of the basin (Fig. 3), the Windsor Group is overlain by siltstone, shale, sandstone, and minor limestone and coal of the upper Mississippian to Pennsylvanian Mabou and Cumberland groups.

The bedrock in the basin is overlain by up to $100 \mathrm{~m}$ of Quaternary and younger glacial till, peat, and clay deposits (MacDougall and Polley 1984; Feetham et al. 2002; Stea et al. 2003, 2006). However, along major northeast-trending faults the Quaternary strata are locally underlain by a fault-bounded package of Cretaceous (ca. $120 \mathrm{Ma}$ ) sand and clay of the Chaswood Formation (Fig. 3).

The vertical ASH-01-1 and ASH-01-2 drillholes targeted one of several positive magnetic anomalies in the basin south of Ashfield (Figs. 3, 4) in hopes of discovering base metal mineralization associated with the Carboniferous basins, as described elsewhere in the province, for example, the Gays River ( $\mathrm{Zn}-\mathrm{Pb})$ and U-Pb-Ag deposits s (e.g., Patterson 1993). After $<8 \mathrm{~m}$ of overburden in ASH-01-1, about 10 m of amygdaloidal basalt was encountered before the hole ended at $17 \mathrm{~m}$ (Fig. 5). Drillhole ASH-01-2, located $50 \mathrm{~m}$ to the southwest on the flank of the same magnetic anomaly, did not encounter basalt but instead $20 \mathrm{~m}$ of grey to red-grey to white mudstone and siltstone interbedded with dark grey-brown limestone and white gypsum (Fig. 5). 
Although recrystallized to very fine-grained granoblastic texture, the limestone still preserves small shelly fossil fragments (Fig. 6a) and the grey mudstone locally displays infilled burrows and rootlets. Trilete spores recovered from the core samples are heavily 'cooked', and only a post-Silurian age could be assigned (R. Fensome, written communication, 2014). However, overall, these sedimentary lithologies are similar to those described at the bottom of the other drillholes in the basin (e.g., Stea et al. 2003, 2006) and are interpreted to be part of the middle to upper Windsor Group.

The earlier drillhole IM-2 near Iron Mines (Fig. 3) bottomed out in amygdaloidal basalt which also broadly coincides with a positive magnetic anomaly in the area (Fig. 4). The upper part of this core consists of about $13 \mathrm{~m}$ of unconsolidated recent sediments with poor recovery of material. Below this interval is about $10 \mathrm{~m}$ of glacially derived red-brown silty clay with rounded pebbles and cobbles (dropstones?) of basalt, sandstone, and various metamorphic lithologies. This clay package overlies $1 \mathrm{~m}$ of brown to grey amygaloidal basalt, in which the core ends (Fig. 5).

No internal contacts are apparent in the basalt sections of these cores to indicate that more than one flow is represented. If the subhorizontal orientation of elliptical amygdules is indicative of the original flow orientation, then the basalts have not been tilted or folded since deposition. The basalt-bearing drillholes were collared at different elevations (IM-2 at $7 \mathrm{~m}$ above mean sea level (amsl) and ASH-01-1 at $23 \mathrm{~m}$ amsl), thus it is uncertain whether the basalt samples represent the same flow or separate flows within a sequence of flows.

The basalt in core ASH-01-1 is dark grey to grey to brown; texture ranges from hyaloophitic to intersertal at the top and grades into finer grained intergranular basalt downward in the core. In the hyalo-ophitic to intersertal basalt, the glassy matrix (40-50\%) is more variolitic with 
abundant radiating plagioclase microlites. The remainder of the rock contains well zoned plagioclase phenocrysts ( $<2 \mathrm{~mm}$ in length), some of which have skeletal and "swallow-tail" textures (30-40\%), and interstitial, partially altered, subhedral grains of augite (10-15\%) (Fig. $6 b)$. The Fe-Ti oxide minerals $(<1 \%)$ are confined to the interstitial spaces between the plagioclase microlites in the glassy matrix. Based on the high magnetic susceptibility measurements $\left(5.51\right.$ to $\left.8.52 \times 10^{-3} \mathrm{SI}\right)$ these minerals are probably magnetite. Amygdules $(<20 \%)$ are filled with clay (montmorillonite?), quartz, carbonate minerals, and unidentified zeolite minerals.

The intergranular basalt deeper in the hole (Figs. 6c, d) contains euhedral well zoned plagioclase ( $<1 \mathrm{~mm}, 70-75 \%)$ with interstitial, brown, partially altered clinopyroxene (20-25\%). The Fe-Ti oxide minerals $(<2 \%)$ form tiny $(<0.25 \mathrm{~mm})$, euhedral crystals and are likely magnetite. Amygdules $(<10 \%)$ are similar to those at the top of the unit.

The basalt in drillhole IM-2 is similar to the lower parts of the basalt in ASH-01-1, but is more altered. It has clinopyroxene that is partially to totally replaced by brown to green chlorite or epidote. The cores of plagioclase are sericitized, and some of the Fe-Ti oxide minerals are altered to hematite, which gives the basalt its brownish colour. Calcite and various zeolite minerals fill amygdules and also occur in veins.

The petrographic features noted above for basalt samples from the Ashfield Formation compare very well with those described for the more extensive North Mountain Formation (Kontak et al. 2002; Kontak 2002, 2008). In particular the plagioclase- and pyroxene-phyric character, the modal percent of phases, and the presence of well-preserved glass in the matrix are distinctive. Thus, these basalts are considered to be petrographic equivalents to those of the 
North Mountain Formation, but due to their limited preservation, it is difficult to correlate to any particular member of those described by Kontak (2008).

Because both drillholes end in basalt, the nature of underlying rocks is unknown and it cannot be confirmed whether or not the Blomidon or Wolfville formations of the Fundy basin farther to the southwest are present. The carbonate rocks in drill core ASH-01-2 are interpreted to be older and part of the Carboniferous Windsor Group based on their shelly fossils. The recrystallized character and baked spores in this core are, attributed to heat from the adjacent basaltic flow(s), or from originally overlying but subsequently eroded basalt. They do not resemble lacustrine carbonate rocks of the Scotts Bay Formation which locally overlie North Mountain Basalt

\section{GEOCHRONOLOGY}

\section{Introduction}

Two samples were selected for whole-rock ${ }^{40} \mathrm{Ar} /{ }^{39} \mathrm{Ar}$ dating using the step-wise heating method. Sample IM-2-73 is from drill core IM-2 at a depth of $22.25 \mathrm{~m}$ near the top of the basalt flow. The second sample (ASH-01-2A) is from drill core ASH-01-1 and was sampled at a depth of $8.5 \mathrm{~m}$, which is also near the top of the basalt flow (Fig. 5). The degree of alteration in these samples is relatively high; however, amygdules and veins were avoided in picking the material for analysis.

\section{Analytical procedures}

The samples were crushed to $<2-3 \mathrm{~mm}$ grain size and the highest quality material visible under binocular observation was handpicked. The concentrates were washed in de-ionized water, dried, and then wrapped in Al-foil. Along with monitors (i.e., Hb3Gr hornblende), the 
concentrates were then stacked in a capsule and irradiated with fast neutrons in position $5 \mathrm{C}$ of the McMaster Nuclear Reactor (Hamilton, Ontario) without Cd shielding for 27 hours (81 MWH with a neutron flux of ca. $4.3 \times 10^{16}$ neutrons $/ \mathrm{cm}^{2}$ ). Details of the subsequent analytical procedures, which were done at the Geochronology Laboratory, Queen's University, Kingston, Ontario, including determining J-values, data reduction, error analysis and age calculations, are provided in Kontak et al. (2005). Dates and errors were calculated using formulae of Dalrymple et al. (1981) and the constants recommended by Steiger and Jager (1977). Errors shown in Table 1 and on the age spectra (Fig. 7) represent analytical precision at $2 \sigma$, assuming that the errors in the ages of the flux monitors are zero. This technique is suitable for comparing within-spectrum variation and determining which steps form a plateau (McDougall and Harrison 1988, p. 89). A conservative estimate of this error in the $\mathrm{J}$-value is $0.5 \%$ and can be added for inter-sample comparison. The dates and J-values are referenced to Hb3Gr hornblende at $1072 \mathrm{Ma}$ (Roddick 1983).

\section{Results}

Sample IM-2-73 has seven steps (Fig. 7a; Table 1) which define the following age data: (1) an integrated age of $212.7 \pm 2.3 \mathrm{Ma}$; (2) a correlation age of $181 \pm 14$ Ma with a moderately high MSWD value of 27; and (3) a weighted mean age of $190 \pm 13$ Ma that used $34.6 \%$ of the gas released in the last 4 steps. The release pattern (Fig. 7a) shows that the first part of the spectrum has a much older age and also lower $\mathrm{Ca} / \mathrm{K}$ ratio than the rest of spectrum, which suggests that the gas was not liberated from the same phase. The latter part of the spectrum, which provides the more robust age data, has a higher $\mathrm{Ca} / \mathrm{K}$ ratio in keeping with gas being 
liberated from plagioclase and is similar to age spectra from samples of the North Mountain Basalt (e.g., Kontak and Archibald 2003; Jourdan et al. 2009).

Sample ASH-01-2A released gas in 12 steps (Fig. 7b; Table 1) which was used to define the following age data: (1) an integrated age of 226.9 $\pm 1.6 \mathrm{Ma}$; (2) a correlation age of $198 \pm 14$ Ma with a very high MSWD value of 67 compared to the previous sample; and (3) a plateau age of $201.8 \pm 2.0 \mathrm{Ma}$ that used $77.5 \%$ of the gas released. The age spectrum for this sample (Fig. 7b) shows an initial segment that is typical of excess argon release. This segment has percentvalues for radiogenic argon that are lower than the higher temperature steps and has low $\mathrm{Ca} / \mathrm{K}$ ratios, The higher temperature steps, in contrast, have $\geq 90 \%$ radiogenic argon, ages between about 195 and $206 \mathrm{Ma}$, and $\mathrm{Ca} / \mathrm{K}$ ratios that are higher and uniform. These higher $\mathrm{Ca} / \mathrm{K}$ ratios are similar to those for fresh whole-rock samples of North Mountain Basalt, as noted above.

The large MSWD values in correlation ages for both samples render them meaningless for geological interpretation.

\section{GEOCHEMISTRY}

Six samples were collected for chemical analysis from basaltic samples in drillholes ASH-01-1 and IM-2 (Table 2). The results are compared to chemical data compiled from published and unpublished studies of Mesozoic basaltic rocks in Atlantic Canada and Maine, hereafter termed simply Fundy Basin flows and dykes. That data set includes analyses from North Mountain Basalt, Dark Harbour Basalt on the island of Grand Manan and related flows encountered in drillholes in the Bay of Fundy, and various Mesozoic dykes from sources cited in the figure captions. 
The 6 analyzed samples from the Ashfield Formation basalt have high loss-on-ignition (7.79 to 17.52 wt. \%) values compared to the Fundy Basin flows and dykes (Fig. 8a). Hence for comparison purposes, the major element oxides in the Fundy Basin samples were recalculated to total $100 \%$ on a volatile-free basis before plotting on the diagrams in Figures 8 and 9, on which representative major element oxides (Fig. 8b-f) and trace elements (Fig. 9) are plotted against $\mathrm{MgO}$ to illustrate chemical variations in these rocks.

The Ashfield Formation samples have lower $\mathrm{MgO}$ contents $(<4.3$ wt. $\%)$ than most flows and dykes from the Fundy Basin (Figs. 8, 9). However, similar low MgO contents have been reported in some samples from the Fundy Basin flows and dykes. The recalculated $\mathrm{SiO}_{2}$ in the Ashfield Formation samples varies between 51.78 and 54.15 wt.\% with an average of 52.95 wt.\%, which is similar to the average $\mathrm{SiO}_{2}$ in basaltic flows and dykes from the Fundy Basin (52.85 and 52.50 wt. \%, respectively). The $\mathrm{Al}_{2} \mathrm{O}_{3}$ is relatively high in the Ashfield Formation samples (average $=17.26$ wt. \%) compared to the Fundy Basin basaltic flows and dykes (average $=14.6$ wt. \%) (Fig. 8c). Both the relatively low $\mathrm{MgO}$ and high $\mathrm{Al}_{2} \mathrm{O}_{3}$ are consistent with the abundance of plagioclase in the Ashfield basalt (up to 75\%) rather than a feature of alteration. Abundances of $\mathrm{Fe}_{2} \mathrm{O}_{3}{ }^{\mathrm{T}}$, $\mathrm{TiO}_{2}$, and $\mathrm{P}_{2} \mathrm{O}_{5}$ are similar to those in the Fundy Basin basaltic flow and dyke samples that have similar low MgO contents (Fig. 8d, e, f).

Nickel and $\mathrm{Cr}$ abundances in the Ashfield Formation basalt are generally low, with averages around 37 and 97 ppm, respectively, consistent with their low MgO contents. The average concentrations of $\mathrm{Nb}(10 \mathrm{ppm}), \mathrm{Y}(22 \mathrm{ppm}), \mathrm{Zr}(120 \mathrm{ppm})$, and V (265 ppm) in these samples are similar to those in samples from the Fundy Basin at 15, 23, 105, and 269 ppm for the flows and 7, 24, 94, and 258 for the dykes (Figs. 8c-f). 
The Ashfield Formation basalt samples are enriched in light rare-earth elements (REE) relative to heavy REE with $(\mathrm{La} / \mathrm{Yb})_{\mathrm{N}}$ ratios varying from about 4.5 to 5.5 (Fig. 10). The Fundy Basin flows and dykes have similar REE patterns but tend to have slightly higher heavy REE (Fig. 10) and hence lower $(\mathrm{La} / \mathrm{Yb})_{\mathrm{N}}$ ratios which range from 2.8 to 4.3 . Both the Ashfield Formation and Fundy Basin samples have either small or no Eu anomalies (Fig. 10).

Based on the total alkalis-silica diagram (Fig. 11a), the Ashfield Formation samples as well as most Fundy Basin flows and dykes are subalkaline basalt or basaltic andesite and plot within the CAMP field. Similarly, using the ratios of the less mobile elements, all of the samples plot in the subalkaline basalt field (Fig. 11b). On the AFM diagram the Ashfield Formation samples plot near the Fe-rich end of the Fe-enrichment tholeiitic trend defined by the majority of Fundy Basin samples (Fig. 12a). The high iron content relative to $\mathrm{MgO}$ is also shown in a plot of $\mathrm{TiO}_{2}$ against $\mathrm{FeO}^{\mathrm{T}} / \mathrm{MgO}$ (Fig. 12b) where the samples plot with a scatter of Fundy Basin samples in the highly differentiated part of the low-Ti continental flood basalt field. On the $\mathrm{Zr} / \mathrm{Y}-\mathrm{Zr}$ diagram (Fig. 13a), the Ashfield Formation samples cluster with the other Fundy Basin samples in the lower Zr part of the within-plate basalt field. As shown in Figure 13b, the slightly higher $\mathrm{TiO}_{2}$ and the higher $(\mathrm{La} / \mathrm{Yb})_{\mathrm{N}}$ ratio are characteristic of the Orange Mountain Group, the stratigraphically lowest group of Mesozoic basalts in the eastern North America CAMP basins in the USA (e.g., Kent and Olsen 2000; Cirilli et al. 2009; Merle et al. 2014; Marzoli et al. 2011).

\section{DISCUSSION}

Overall, the chemical characteristics of the Ashfield Formation basaltic flows are consistent with those of the basalt flows and dykes in the Fundy Basin, and with CAMP in general, although they are at the extreme low $\mathrm{MgO}$ part of the spectrum. They are comparable, as 
noted, with the Orange Mountain Group flows to the south. The plateau age of $201.8 \pm 2.0 \mathrm{Ma}$ from sample ASH-01-2A is also similar to ages reported from Fundy Basin flows and dykes. Whole-rock and plagioclase ${ }^{40} \mathrm{Ar} /{ }^{39} \mathrm{Ar}$ ages obtained from the North Mountain Basalt range from $197.0 \pm 1.0$ to $201.5 \pm 1.1 \mathrm{Ma}$ (Kontak and Archibald 2003; Jourdan et al. 2009), and U-Pb zircon ages between 201.3 \pm 0.1 and 201.7 \pm 1.4 Ma (Hodych and Dunning 1992; Schoene et al. 2006, 2010; Blackburn et al. 2013). Many of the flows, sills and dykes related to CAMP in eastern North America have similar ages (Fig. 14).

Although the second Ashfield Formation sample (IM-2-73) yielded a less robust younger ${ }^{40} \mathrm{Ar} /{ }^{39} \mathrm{Ar}$ whole rock age of ca. $190 \mathrm{Ma}$, the $\mathrm{Ca} / \mathrm{K}$ ratio for the "age-segment" is typical of relatively unaltered basalt of the North Mountain (Kontak and Archibald 2003). Similar ${ }^{40} \mathrm{Ar} /{ }^{39} \mathrm{Ar}$ whole rock and plagioclase ages (weighted mean average of $190.8 \pm 1.3 \mathrm{Ma}$ ) have been obtained elsewhere in the Newark Supergroup, some with statistically more robust ages than our data. In addition, ages that range from 190 to 194 Ma have been previously recorded for CAMP in South America and Africa (cf. Jourdan et al. 2009) and are coincident with the younger K/Ar whole rock and plagioclase ages (Fig. 14). These younger ages have been attributed to (1) complications in the argon systematics (Jourdan et al. 2009), (2) a younger intrusive (crystallization) event (Jourdan et al. 2009), or (3) a younger hydrothermal event coincident with zeolite formation in the North Mountain Basalt (Kontak and Archibald 2003) and sulphide mineralization related to the Caraquet Dyke in central New Brunswick (Crosby et al. 1990). The younger hydrothermal hypothesis is consistent with the observation that zeolites occur not only in flows but also as cross-cutting veins through the North Mountain Basalt and overlying McCoy Brook and Scots Bay formations (Kontak 2000, 2008; Pe-Piper and Miller 2002). The younger sulphide mineralization post-dated crystallization of the Caraquet Dyke and 
is associated with NE-SW-trending breccia zones that parallel the Mesozoic faults bordering the Mesozoic Fundy Basin which were active up the Cenozoic (Stringer and Lajtai 1979; Crosby et al. 1990). Hence, hydrothermal activity post-dated eruption and cooling of the basaltic sequence and deposition of the overlying Jurassic sediments. In the same way, the ca. 189 Ma age from sample IM-2-73 may reflect the later alteration of the Ashfield Formation basalt, whereas the age of ca. 201 Ma from sample ASH-01-1 better reflects the time of igneous crystallization.

The presence of basalt in holes IM-2 and ASH -01-1 suggests that similar areas of elevated aeromagnetic response in the River Denys Basin may also be caused by basalt of the Ashfield Formation (Fig. 4). Similar, small aeromagnetic anomalies in other Carboniferous basins in southwestern Cape Breton Island (King 2003b, c) may also represent Mesozoic basaltic flows. Field investigation in the areas of these anomalies did not reveal any evidence for the source, and hence drilling is required in order to confirm the extent of Mesozoic basalt in these basins. Some of the magnetic anomalies in the Carboniferous basins may be Carboniferous basalt flows or gabbroic plutons, which are also known to occur in the area (Barr et al. 1994).

Based on field and petrographic evidence, McHone (1996) suggested that Triassic sedimentary rocks and Early Jurassic basalts were once much more extensive across northeastern North America, following the 'broad terrane' model of Russell (1980), and that later basement uplift led to erosion and isolation of the present early Mesozoic basins. In contrast, Pe-Piper and Piper (1999) argued on lithogeochemical grounds that basalt distribution was more limited and hence favoured a 'restricted basin' model. The recognition of Early Mesozoic volcanic rocks in the River Denys Basin of southwestern Cape Breton Island provides new evidence for a broader distribution of these rocks than previously recognized. The latter supposition becomes relevant when defining the entirety of CAMP magmatism and how it relates to the global biologic crisis 
given that these rocks are implicated in the end Triassic extinction event (e.g., McHone 2003;

Blackburn et al. 2013 and references therein).

\section{CONCLUSIONS}

At least two of the numerous positive aeromagnetic anomalies in the River Denys Basin are now known to be caused by basaltic flows of the Ashfield Formation, which underlie glacial deposits. A whole-rock ${ }^{40} \mathrm{Ar} /{ }^{39} \mathrm{Ar}$ plateau age of $201.8 \pm 2 \mathrm{Ma}$ from one basalt sample overlaps with previous $\mathrm{U}-\mathrm{Pb}$ zircon and ${ }^{40} \mathrm{Ar} /{ }^{39} \mathrm{Ar}$ whole rock and plagioclase ages from flow basalts and related dykes in the Newark Supergroup. A younger ${ }^{40} \mathrm{Ar} /{ }^{39} \mathrm{Ar}$ whole-rock age of ca. 190 Ma age from a second basalt sample is similar to other younger ages throughout the Newark Supergroup which are interpreted to reflect a younger hydrothermal alteration event and subsequent zeolite formation.

Major and trace element data from six samples of the Ashfield Formation basalt indicate that it is low-Ti continental tholeiite formed in a within-plate tectonic setting. The chemistry of the basalts resembles that of basaltic flows in the Fundy and Grand Manan basins. The new ages combined with the geochemistry demonstrate the presence of Mesozoic basaltic flows in the River Denys Basin. An implication of this study is that more of these basalts and possibly associated rift-related sedimentary rocks may be buried under glacial deposits in Carboniferous basins of Cape Breton Island.

\section{ACKNOWLEDGEMENTS}


This work was funded by the Nova Scotia Department of Natural Resources, and their support, both financial and otherwise, is appreciated. This project also benefited from funding provided by the first federal-provincial Targeted Geoscience Initiative (TGI-1). The argon analyses were done in the Geochronology Laboratory, Queen's University, which is supported by NSERC infrastructure grants. We thank M. O'Neil in the NSDNR Stellarton Core Library for facilitating access to the core and J. Greenough for access to unpublished geochemical data form the North Mountain Basalt. We also thank J. Breton and T. Lenfesty, NSDNR librarians, for assistance in acquiring unpublished thesis material and other obscure documents, and S. Barr and E. MacDonald for advice and editing of an earlier version of the manuscript. Journal reviewers J. D. Greenough and J. G. McHone provided valued comments that resulted in an improved manuscript. This paper is published with permission of the Director, Nova Scotia Department of Natural Resources.

\section{REFERENCES}

Albarède, F. 1992. How deep do common basaltic magmas form and differentiate? Journal of Geophysical Research, 97, pp. 10997-11009.

Armstrong, R. L. and Besancon, J. 1970. A Triassic time-scale dilemma: K-Ar dating of Upper Triassic mafic igneous rocks, eastern U.S.A. and Canada and post Upper Triassic plutons, western Idaho, U.S.A. Eclogae Geologica Helvetiae, 63, pp. 15-28.

Baksi, A.K. 2007. A quantitative tool for detecting alteration in undisturbed rocks and mineral II: application to argon ages related to hotspots. In Plates, Plumes and Planetary Processes. Edited by G.R. Foulger and D.M. Jurdy. Geological Society of America Special Paper, 430, pp. $305-333$. 
Barr, S. M. and Raeside, R. P. 1989. Tectonostratigraphic terranes in Cape Breton Island, Nova Scotia: implications for the configuration of the northern Appalachian Orogen. Geology, 17, p. $822-825$.

Barr, S.M., Grammatikopoulos, A.L., and Dunning, G.R. 1994. Early Carboniferous gabbro and basalt in the St. Peters area, southern Cape Breton Island, Nova Scotia. Atlantic Geology, 30, 247-258.

Benoit, M. H., C. Ebinger, and Crampton, M. 2014, Orogenic bending around a rigid Proterozoic magmatic rift beneath the Central Appalachian Mountains, Earth Planet. Sci. Lett., 402, 197208.

Bertrand, H., Dostal, J., Dupuy, C. 1982. Geochemistry of Mesozoic tholeiites from Morocco. Earth and Planetary Sciences Letters, 58, 225-239.

Blackburn, T.J., Olsen, P.E., Bowring, S.A., McLean, N.M., Kent, D.V., Puffer, J., McHone, G., Rasbury, E.T., and Et-Touhami, M. 2013. Zircon U-Pb geochronology links the end-Triassic extinction with the Central Atlantic Magmatic Province. Science, 340, pp. 941-945.

Cirilli, S., Marzoli, A., Tanner, L., Bertrand, H., Buratti, N., Jourdan, F., Bellieni, G., Kontak, D., and Renne, P.R. 2009. Latest Triassic onset of the Central Atlantic Magmatic Province (CAMP) volcanism in the Fundy Basin (Nova Scotia): New stratigraphic constraints: Earth and Planetary Science Letters, v. 286, pp. 514-525.

Crosby, J.D., Greenough, J.D., Hattie, D., and Venugopal, D.V. 1990. Post-Triassic mineralization in central New Brunswick: implications of the McBean Brook Zn-Pb-Ag occurrence. Atlantic Geology, 26, pp. 1-9.

Dallmeyer, R.D. 1975. The Palisades Sill: A Jurassic intrusion? Evidence from ${ }^{40} \mathrm{Ar} /{ }^{39} \mathrm{Ar}$ incremental release ages. Geology, 3, pp. 243-245. 
Dalrymple, G.B., Alexander, E.C., Lanphere, M.A. and Kraker, G.P. 1981. Irradiation of samples for ${ }^{40} \mathrm{Ar} /{ }^{39} \mathrm{Ar}$ dating using the Geological Survey TRIGA reactor. U.S. Geological Survey, Professional Paper, 1176, 55 p.

Dostal, J. and Dupuy, C. 1984. Geochemistry of the North Mountain basalts (Nova Scotia, Canada). Chemical Geology, 45, pp. 245-261.

Dostal, J. and Durning, M. 1998. Geochemical constraints on the origin and evolution of early Mesozoic dikes in Atlantic Canada. European Journal of Mineralogy, 10, pp. 79-93.

Dostal, J. and Greenough, J.D. 1992. Geochemistry and petrogenesis of the Early Mesozoic North Mountain Basalts of Nova Scotia, Canada. In Eastern North American Mesozoic Magmatism. Edited by J.H. Puffer and P.C. Ragland. Geological Society of America, Special Paper 268, pp. 149-159.

Dunn, A.M. 1994. The geochemistry and geochronology of the Shelburne dyke of Nova Scotia and the Messejana dyke of Spain. Unpublished B.Sc. H. thesis, Dalhousie University, Halifax. Nova Scotia, 111 p.

Dunn, A.M., Reynolds, P.H., Clarke, D.B., and Ugidos, J.M. 1998. A comparison of the age and composition of the Shelburne dyke, Nova Scotia, and the Messejana dyke, Spain. Canadian Journal of Earth Sciences, 35, pp. 1110-1115.

Dunn, T. and Stringer, P. 1990. Petrology and petrogenesis of the Ministers Island dyke, southwest New Brunswick, Canada. Contributions to Mineralogy and Petrology, 105, pp. 5565.

Dunning, G. R., and J. P. Hodych. 1990. U/Pb zircon and baddeleyite ages for the Palisades and Gettysburg sills of the northeastern United States: Implications for the age of the Triassic/Jurassic boundary, Geology, 18, pp. 795-798. 
Dunning, G.R., Barr, S.M., Giles, P.S., McGregor, D.C., Pe-Piper, G., and Piper, D.J.W. 2002. Chronology of Devonian to early Carboniferous rifting and igneous activity in southern Magdalen Basin based on U-Pb (zircon) dating. Canadian Journal of Earth Sciences, 39, pp. 1219-1237.

Feetham, M., Stea, R.R, and Pullan, S.E. 2002. Progress report on data compilation, surficial mapping, seismic surveys and drilling for the Targeted Geoscience Initiative Project in southcentral Cape Breton Island. ). In Mineral Resources Branch, Report of Activities 2001. Nova Scotia Department of Natural Resources, Report 2002-1, pp. 29-37.

Greenough, J.D., and Dostal, J. 1992. Cooling history and differentiation of a thick North Mountain Basalt flow (Nova Scotia, Canada). Bulletin Volcanology and Geothermal Research 55, 63-73.

Greenough, J.D., and Papezik, V.S. 1986. Petrology and geochemistry of the early Mesozoic Caraquet dyke, New Brunswick, Canada. Canadian Journal of Earth Sciences, 23, pp. 193201.

Greenough, J.D. and Papezik, V.S. 1987. Note on the petrology of North Mountain Basalt from the wildcat oil well Mobil Gulf Chinampas N-37, Bay of Fundy, Canada. Canadian Journal of Earth Sciences, 24, pp. 1255-1260.

Greenough, J. D., Jones, L.M., and Mossman, D.J. 1989. Petrochemical and stratigraphic aspects of North Mountain basalts from the north shore of the Bay of Fundy, Nova Scotia, Canada. Canadian Journal of Earth Sciences, 26, pp. 2710-2727.

Hames, W.E., Renne, P.R., and Ruppel, C. 2000. New evidence for geologically instantaneous emplacement of earliest Jurassic Central Atlantic Magmatic Province basalts on the North American margin. Geology, 28, pp. 859-862. 
Hibbard, J.P., van Staal, C.R., Rankin, D.W., and Williams, H. 2006. Lithotectonic map of the Appalachian Orogen, Canada-United States of America; Geological Survey of Canada, Map 2096A, scale 1:1500 000 .

Hodych, J.P. and Dunning, G.R. 1992. Did the Manicouagan impact trigger end-of-Triassic mass extinction? Geology, 20, pp. 51-54.

Hodych, J.P. and Hayatsu, A. 1988. Paleomagnetism and K -Ar isochron dates of Early Jurassic basaltic flows and dykes of Atlantic Canada. Canadian Journal of Earth Sciences, 25, pp. $1972-1989$.

Irvine, T. N. and Baragar, W. R. A. 1971. A guide to the chemical classification of the common volcanic rocks. Canadian Journal of Earth Sciences 8, pp. 523-548.

Jourdan, F., Marzoli, A., Bertrand, H., Cirilli, S, Tanner, L., Kontak, D.J., McHone, G., Renne, P.R., and Bellieni' G. 2009. ${ }^{40} \mathrm{Ar} /{ }^{39} \mathrm{Ar}$ ages of CAMP in North America: Implications for the Triassic-Jurassic boundary and the ${ }^{40} \mathrm{~K}$ decay constant bias. Lithos, 110, p. 167-180.

Kelley, D. G. 1967. Baddeck and Whycocomagh map areas with emphasis on the Mississippian stratigraphy of central Cape Breton Island, Nova Scotia (11 K/2 and $11 \mathrm{~F} / 14)$. Geological Survey of Canada, Memoir 351, 65 p.

Kent, D. V. and Olsen, P. E., 2000, Magnetic polarity stratigraphy and paleolatitude of the Triassic--Jurassic Blomidon Formation in the Fundy basin (Canada): implications for early Mesozoic tropical climate gradients. Earth and Planetary Science Letters, 179, pp. 311-324.

King, M.S. 2003a. Airborne magnetic calculated second vertical derivative map for NTS 11F/14, Whycocomagh area, Nova Scotia. Nova Scotia Department of Natural Resources Branch,, Open File Map ME 2003-8, scale 1:50 000. 
King, M.S. 2003b. Airborne magnetic calculated second vertical derivative map for part of the Targeted Geoscience Initiative Project area, south-central Cape Breton island, Nova Scotia. Nova Scotia Department of Natural Resources Branch, Open File Map ME 2003-35 scale 1:100000.

King, M.S. 2003c. Airborne magnetic first vertical derivative map for part of the Targeted Geoscience Initiative Project area, south-central Cape Breton Island, Nova Scotia. Nova Scotia Department of Natural Resources Branch, Open File Map ME 2003-34 scale 1:100 000.

Klein, G.de V. 1962. Triassic sedimentation, Maritime Provinces, Canada. Geological Society of America Bulletin, 73, pp. 1127-1146

Kontak, D.J. 2000. Nature of zeolite distribution in the North Mountain Basalt, southern Nova Scotia: Field and geochemical studies. In Nova Scotia Department of Natural Resources, Minerals and Energy Branch, Report of Activities 1999. Edited by D.R. MacDonald. Report 2000-1, pp. 105-123.

Kontak, D.J., 2002. Internal stratigraphy of the Jurassic North Mountain Basalt, southern Nova Scotia. In Mines and Minerals Branch Report of Activities 2001. Edited by D.R. MacDonald. Nova Scotia Department of Natural Resources, Report 2002-1, pp. 69-79.

Kontak, D.J. 2008. On the edge of CAMP: geology and volcanology of the Jurassic North Mountain Basalt, Nova Scotia. Lithos, 101, pp. 74-101.

Kontak and Archibald, D.A. 2003. ${ }^{40} \mathrm{Ar} /{ }^{39} \mathrm{Ar}$ age dating of the Jurassic North Mountain Basalt, southern Nova Scotia. Atlantic Geology, 39, pp. 47-54. 
Kontak, D.J., DeWolfe, M., Dostal, J., 2002. Late-stage crystallization history of the Jurassic North Mountain Basalt, Nova Scotia: I. Evidence for pervasive silicate-liquid immiscibility. Canadian Mineralogist, 40, pp. 1287-1311.

Kontak, D.J., Creaser, R., Heaman, L., and Archibald, D.A. 2005. U-Pb tantalite, Re-Os moybendite, and ${ }^{40} \mathrm{Ar} /{ }^{39} \mathrm{Ar}$ muscovite dating of the Brazil Lake pegmatite, Nova Scotia: A possible shear-zone related origin for an LCT-type pegmatite. Atlantic Geology, 41, pp. 1730.

Lawrence, D.E. 1966. A contribution to the petrology of the Great Dyke of Nova Scotia. Unpublished M.Sc. thesis, Dalhousie University, Halifax, Nova Scotia, 108 p.

LeBas, M.J., Lemaitre, R.W., Streckeisen, A. and Zanettin, B. 1986. A chemical classification of volcanic rocks based on the total alkali - silica diagram. Journal of Petrology 27(3): 745-750.

Liew, M.Y.C. 1976. Struture, geochemistry, and stratigraphy of Triassic rocks, north shore of Minas Basin, Nova Scotia. Unpublished M.Sc. thesis, Acadia University, Wolfville, Nova Scotia, $181 \mathrm{p}$.

MacDougall, I. and Polley, D.E. 1984. Drilling logs of government core drills 1983. Report 84-5. Nova Scotia Department of Mines and Energy, 38 p.

Marzoli, A., Renne, P.R., Piccirillo, E.M., Ernesto, M., Bellieni, G., DeMin, A. 1999. Extensive 200-Million-Year- Old continental flood basalts of the Central Atlantic Magmatic Province. Science, 284, pp. 616-618.

Marzoli, A., Bertrand, H., Knight, K., Cirilli, S., Buratti, N., Verati, C., Nomade, S., Renne, P. R., Youbi, N., Martini, R., Allenbach, K., Neuwerth, R., Rapaille, C., Zaninetti, L., and Bellieni, G. 2004. Synchrony of the Central Atlantic Magmatic province and the TriassicJurassic boundary climatic and biotic crisis. Geology, 32, pp. 973-976. 
Marzoli, A., Jourdan, F., Puffer, J. H., Cuppone, T., Tanner, L. H., Weems, R. E., Bertrand, H., Cirilli, S., Bellieni, G., and De Min, A. 2011.Timing and duration of the Central Atlantic magmatic province in the Newark and Culpeper basins, eastern USA. Lithos, 122, pp. 175188.

McDougall, I. and Harrison, T.M. 1988. Geochronology and thermochronology by the ${ }^{40} \mathrm{Ar} /{ }^{39} \mathrm{Ar}$ method. Oxford Monographs on Geology and Geophysics No. 9, Oxford University Press, New York, 212 p.

McHone, J.G. 1992. Mafic dike suites within Mesozoic igneous provinces of New England and Atlantic Canada. In Eastern North American Mesozoic Magmatism. Edited by J.H. Puffer and P.C. Ragland. Geological Society of America Special Paper, 268, pp. 1-11.

McHone, J.G. 1996. Broad-terrane Jurassic flood basalts across northeastern North America. Geology, 24, pp. 319-322.

McHone, J. G. 2000. Non-plume magmatism and tectonics during the opening of the central Atlantic Ocean. Tectonophysics, 316, pp. 287-296.

McHone, J.G. 2003. Volatile emissions from Central Atlantic Magmatic Province Basalts: Mass assumptions and environmental consequences. In The Central Atlantic Magmatic Province. American Geophysical Union Monograph 136, pp. 241-254.

McHone, J.G. 2011. Triassic basin stratigraphy at Grand Manan, New Brunswick, Canada. Atlantic Geology, 47, pp. 125-137.

McHone, J.G. and Fyffe, L.H. 2014. Geology of the Island of Grand Manan, New Brunswick: Precambrian to Early Cambrian and Triassic Formations. Field Trip B3. Geological Association of Canada - Mineralogical Association of Canada Joint Meeting, Fredericton, New Brunswick, May 2014, 78 p. 
McHone, J.G., Ross, M.E., and Greenough, J.D. 1987. Mesozoic dyke swarms of eastern North America, In Mafic dyke swarms. Edited by H.C. Halls and W.H. Fahrig. Geological Association of Canada, Special Paper 34, pp. 102-111.

McHone, J.G., Hussey, A.M. II, West, D.P. Jr., and Bailey, D.G. 2014. The Christmas Cove Dyke of coastal Maine, USA and regional sources for Early Mesozoic flood basalts in Northeastern North America. Atlantic Geology, 50, pp. 66-90.

Merle, R., Marzoli, A., Reisberg, L., Bertrand, H., Nemchin, A., Chiaradia, M., Callegaro, S., Jourdan, F., Bellieni, G., Kontak, D., Puffer, J., and McHone, J.G. 2014. Sr, Nd, Pb and Os isotope systematics of CAMP tholeiites from Eastern North America (ENA): Evidence of a subduction-enriched mantle source. Journal of Petrology, 55, pp.133-180.

Murphy, J. B., Dostal, J., Gutieorrez-Alonso, G., and Keppie, J. D. 2011. Early Jurassic magmatism on the northern margin of CAMP: Derivation from a Proterozoic sub-continental lithospheric mantle. Lithos, 123, pp. 158-164.

Nomade, S., Knight, K.B., Beutel, E., Renne, P.R., Verati, C., Féraud, G., Marzoli, A., Youbi, N., and Bertrand, H. 2007. Chronology of the Central Atlantic Magmatic Province: Implications for the Central Atlantic rifting processes and the Triassic-Jurassic biotic crisis: Palaeogeography, Palaeoclimatology, Palaeoecology, 244, pp. 326-344.

O'Loughlin, J.P.S. 1977. Chemical and metamorphic petrology of the Triassic lavas of the north shore of Minas Basin, Nova Scotia. Unpublished BSc. Thesis. Brock University, St. Catherines, Ontario, $47 \mathrm{p}$.

Olsen, P.E. 1978. On the use of the term Newark for Triassic and Early Jurassic rocks of eastern North America. Newsletter on Stratigraphy, 7, pp. 90-95. 
Olsen, P. E. 1988. Paleoecology and paleoenvironments of the continental Early Mesozoic Newark Supergroup of eastern North America. In Triassic-Jurassic rifting and the opening of the Atlantic Ocean. Edited by W. Manspeizer. Elsevier, Amsterdam, pp. 185-230.

Papezik, V.S., and Barr, S.M. 1981. The Shelburne dyke, an early Mesozoic diabase dyke in Nova Scotia: Mineralogy, petrology, and regional significance. Canadian Journal of Earth Sciences, 18, pp. 1346-1355.

Papezik, V.S., Greenough, J.D., Colwell, J.A., and Mallinson, T.J. 1988. North Mountain basalt from Digby, Nova Scotia: models for a fissure eruption from stratigraphy and petrochemistry. Canadian Journal of Earth Sciences, 25, pp. 74-83.

Papezik, V.S. and Hodych, J.P. 1980. Early Mesozoic diabase dikes of the Avalon Peninsula, Newfoundland: petrochemistry, mineralogy and origin. Canadian Journal of Earth Sciences, 17, pp. 1417-1430.

Patterson, J.M. 1993. Metalliferous Environments in Nova Scotia (Base Metals). Nova Scotia Department of Natural Resources Mineral Resources Branch Information Series ME 22, 69 p.

Pearce, J.A. 1996. A users guide to basalt discrimination diagrams, in Wynam, D.A., ed., 477 Geological Association of Canada, Short Course Notes, 12, pp. 79-113.

Pearce, J.A. and Cann, J.R., 1973. Tectonic setting of basic volcanic rocks determined using trace element analyses. Earth and Planetary Science Letters, 19, pp. 290-300.

Pe-Piper, G. and D. J. W. Piper 1999. Were Jurassic tholeiitic lavas originally widespread in southeastern Canada?: a test of the broad terrane hypothesis. Canadian Journal of Earth Sciences, 36, pp. 1509-1516. 
Pe-Piper, G. and Miller, L., 2002. Zeolite minerals from the North Shore of the Mines Basin, Nova Scotia. Atlantic Geology, 38, pp. 11-28.

Pe-Piper, G., Jansa, L.F., and Lambert, R.St.J. 1992. Early Mesozoic magmatism on the eastern Canadian margin: petrogenetic and tectonic significance. In Eastern North American Mesozoic Magmatism. Edited by J.H. Puffer and P.C. Ragland. Geological Society of America, Special Paper 268, pp. 13-36.

Roddick, J.C. 1983. High precision intercalibration of ${ }^{40} \mathrm{Ar} /{ }^{39} \mathrm{Ar}$ standards. Geochimica et Cosmochimica Acta, 47, pp. 87-898.

Russell, I.C. 1980. On the former extent of the Triassic formation of the Atlantic states. American Naturalist, 14, pp. 703-712.

Schoene, B., Crowley, J.L., Condon, D.J.,Schmitz, M.D., and Bowring, S.A. 2006. Reassessing the uranium decay constants for geochronology using ID-TIMS U-Pb data. Geochimica et Cosmochimica Acta, 70, pp. 426-445.

Schoene, B., Guex, J., Bartolini, A., Schaltegger, U., and Blackburn, T.J. 2010. Correlating the end-Triassic mass extinction and flood basalt volcanism at the 100 ka level. Geology, 38, pp. $387-390$.

Seiderman, D.E., Masterson, W.D., Dowling, M. P., and Turekian, K. K. 1984. K-Ar dates and ${ }^{40} \mathrm{Ar} /{ }^{39} \mathrm{Ar}$ age spectra for Mesozoic basalt flows of the Hartford Basin, Connecticut, and the Newark Basin, New Jersey. Geological Society of America Bulletin, 95, pp. 594-598.

Sinha, P. 1970. Petrology of volcanic rocks of North Mountain, Nova Scotia. Unpublished Ph.D. thesis, Dalhousie University, Halifax, Nova Scotia, 156 p.

Stea, R. R., Pullan, S. E., and Feetham, M. 2003. Mesozoic-Cenozoic Stratigraphy of the Lowlands of Southwest Cape Breton Island (NTS 11F/11, 11F/14). In Mineral Resources 
Branch, Report of Activities 2002; Nova Scotia Department of Natural Resources, Report 2003-1, pp. 103-126.

Stea, R.R., Feetham, M., Pullan, S.E., Ostrom, W., Baechler, L., and Ryan, R.J. 2006. Geology and economic potential of the glacial clay and sand deposits of Inverness county, southwest Cape Breton Island. Nova Scotia Department of Natural Resources, Economic Geology Series, ME 2006-1, 105 p.

Steiger, R.H. and Jager, E. 1977. Subcommission on geochronology: Convention and use of decay constants in geo- and cosmo-chronology. Earth and Planetary Science Letters, 36, pp. $359-362$.

Stringer, P. and Burke, K.B.S. 1985. Structure in southwest New Brunswick. Geological Association of Canada/Mineralogical Association of Canada, Field Trip Guidebook, Excursion 9, 34 p.

Stringer, P. and Lajtai, E.Z., 1979. Cleavage in Triassic rocks of Southern New Brunswick, Canada. Canadian Journal of Earth Sciences, 16, pp. 2165-2180.

Sues, H.-D. and Olsen, P.E. 2015. Stratigraphic and temporal context and faunal diversity of Permian-Jurassic continental tetrapod assemblages from the Fundy rift basin, eastern Canada. Atlantic Geology, 51, pp. 139-205.

Sun, S. S., and McDonough, W. F. 1989. Chemical and isotopic systematics of oceanic basalts: implications for mantle composition and processes. In Magmatism in the Ocean Basins. Edited by A.D. Saunders and M.J. Norry. Geological Society, London, Special Publications, 42 , pp. 313-345.

Tanner, L.H. and Brown, D.E. 1999. The Upper Triassic Chedabucto Formation, Guysborough County, Nova Scotia: depositional and tectonic context. Atlantic Geology, 35, pp.129-138. 
Tanner, L. H. and Brown, D. E., 2003. Tectonostratigraphic evolution of the Orpheus Graben, Scotian Basin, offshore Eastern Canada: Analogies to the Fundy Rift Basin. In The Great Rift Valleys in Eastern North America - Sedimentology, Stratigraphy and Paleontology Volume 2. Edited by P.M. LeTourneau and P.E. Olsen. Special Conference Volume, Columbia University Press, pp.59-68.

Verati, C., Rapaille, C., Féraud, G., Marzoli, A., Bertrand, H., Youbi, N., 2007. Timing the Tr-J boundary: further constraints on duration and age of the CAMP volcanism recorded in Morocco and Portugal. Palaeogeography Palaeoclimatology Palaeoecology, 246, pp. 308325.

Wade, J.A., Brown, D.E., Traverse, A., and Fensome,R.A. 1996. The Triassic-Jurassic Fundy Basin, eastern Canada: regional setting, stratigraphy and hydrocarbon potential. Atlantic Geology, 32, pp. 189-231.

Wark, J.M. 1980. Paleotectonic environment of the North Mountain basalt, Nova Scotia: a geochemical approach. Unpublished M.Sc. thesis, Dalhousie University, Halifax, Nova Scotia, $156 \mathrm{p}$.

Wark, J.M., and Clarke, D.B. 1980. Geochemical discriminators and the palaeotectonic environment of the North Mountain basalts, Nova Scotia. Canadian Journal of Earth Sciences, 1980, 17(12): 1740-1745.

Weston Geophysical. 1977. Geological and seismological investigations for Pilgrim Unit II of Boston Edison. U.S. Nuclear Regulatory Commission Document BE-SG7603, Appendix G$6,19 \mathrm{p}$

Whalen, L., Gazel, E., Vidito, C., Puffer, J., Bizimis, M., Henika, W., and Caddick, M.J. 2015. Supercontinental inheritance and its influence on supercontinental breakup: The Central 
Atlantic Magmatic Province and the break up of Pangea, Geochemistry, Geophysics.

Geosystems, 16, on line article, accessed November 2015.

White, C.E. and Barr, S.M. 1998. Preliminary geological map of Guysborough, Richmond and Antigonish Counties (parts of NTS sheets 11E/08, 11F/05, 11F/06, 11F/10, 11F/11, 11F/12 and 11F/15), Nova Scotia, Canada. Nova Scotia Department of Natural Resources, Minerals and Energy Branch, Open File OFM 1998-001; scale 1:100 000.

White, C.E. and Barr, S.M. 1999. Geology of the Guysborough-Mulgrave-L'Ardoise area: A progress report. In Nova Scotia Department of Natural Resources, Minerals and Energy Branch, Report of Activities 1998, Edited by D.R. MacDonald and K.A. Mills. Report ME 1999-1, pp. 105-117.

White, C.E. and Boehner, R.C. 2008. Bedrock Geology Map of the Whycocomagh Area (NTS 11F/14), Inverness County, Nova Scotia. Nova Scotia Department of Natural Resources, Mineral Resources Branch, Open File Map ME2008-1; scale 1:50 000.

White, C.E., Barr, S.M., Davis, D.W., Swanton, D.S., Ketchum, J.W.F., and Reynolds, P.H. 2016. Field relations, age, and tectonic setting of metamorphic and plutonic rocks in the Creignish Hills - North Mountain area, southwestern Cape Breton Island, Nova Scotia, Canada. Atlantic Geology, 52: 35-57.

Winchester, J.A. and Floyd, 1976, Geochemical magma type discrimination. Application to altered and metamorphosed basic igneous rocks: Earth and Planetary Science Letters, 28, pp. 459-469.

\section{Figure Captions}


Figure 1. A pre-rift (earliest Jurassic) map of Pangaea adapted from McHone (2003) and Benoit et al. (2014) showing the distribution of dykes, sills, and lavas of the Central Atlantic Magmatic Province (CAMP) and Mesozoic rift basins. Abbreviations: NL, Newfoundland; NS, Nova Scotia; SC, South Carolina.

Figure 2. Generalized locations of Early Mesozoic basins (green) and related tholeiitic dykes in the Maritime Provinces of Canada. The black box indicates the study area, which is also shown in Figure 3.

Figure 3. Simplified geological map of the River Denys Basin in southwestern Cape Breton Island modified from White and Boehner (2008) showing the distribution of the Ashfield Formation (in green) based on drilling. Other inferred subsurface locations of basalt (in yellow) are based on the aeromagnetic anomalies shown in Figure 4.

Figure 4. Airborne magnetic map of the River Denys Basin calculated for its second vertical derivative (after King 2003a). The inferred locations of subsurface basaltic flows are shown by the arrows. Note that the linear aeromagnetic anomalies along the western margin of the map area are known to be the subsurface extensions of the older basement blocks.

Figure 5. Stratigraphic columns of the drillholes shown on Figure 3: IM-2 (UTM Zone 20; E = 5089007, $\mathrm{N}=643557)$, ASH-01-1 (UTM Zone 20; $\mathrm{E}=5080806, \mathrm{~N}=642721)$, and ASH-012 (UTM Zone 20; $\mathrm{E}=5080759, \mathrm{~N}=642699)$. Note that the locations of samples for 
${ }^{40} \mathrm{Ar} /{ }^{39} \mathrm{Ar}$ dating and geochemistry are shown in boxes whereas the filled circles are thin section locations.

Figure 6. Photomicrographs, all in plane polarized light, from drill core samples. The scale bar in upper left of each image is $0.50 \mathrm{~mm}$. (a) Recrystallized fossil in a skeletal limestone from $21.4 \mathrm{~m}$ in drill core ASH-01-2. (b) Basalt with stubby rectangular plagioclase and partially altered augite phenocrysts in a groundmass of black glass and elongate plagioclase laths. Arrows indicate swallow-tail textures (sample ASH-01-2B, 8.75 m). (c) Basalt with augite phenocryst in a fine-grained matrix of plagioclase and glass (sample ASH-01-2A, $8.50 \mathrm{~m}$ ). (d) Amygdaloidal basalt with plagioclase and augite phenocrysts in glassy matrix (sample ASH-01-2C, $10.9 \mathrm{~m})$. Some of the plagioclase laths have swallow-tail textures. Abbreviations: $\mathrm{pl}=$ plagioclase; aug = augute; $\mathrm{g}=$ glass, amy = amygdaloidal.

Figure 7. Plots of $\mathrm{Ca} / \mathrm{K}$ release with cumulative ${ }^{39} \mathrm{Ar}$ fraction and ${ }^{40} \mathrm{Ar} /{ }^{39} \mathrm{Ar}$ age spectra plots for the two samples dated in this study. (a) Zeolite-bearing altered basalt (sample IM-2-73) from drillhole IM-2, and (b) fresh basalt (sample ASH-01-2A) from drillhole ASH-01-1. Steps that define the plateau age are in red. Note the break in the age-scale. Abbreviations: IA = integrated age, $\mathrm{PA}=$ plateau age, $\mathrm{CA}=$ correlation age.

Figure 8. Binary element diagrams comparing samples from the Ashfield Formation to Fundy Basin flows and dykes. (a) $\mathrm{SiO}_{2}$ plotted against LOI (loss-on-ignition). (b-f) Major element oxides (weight \%) plotted against MgO. Data in (b-f) have been recalculated on a volatilefree basis. Chemical data from the Fundy Basin were compiled mainly from Dostal and 
Dupuy (1984), Dostal and Durning (1998), Dostal and Greenough (1992), Dunn (1994),

Dunn and Stringer (1990), Greenough and Dostal (1992), Greenough and Papezik (1986),

Greenough and Papezik (1987), Greenough et al. (1989), Lawrence (1966), Liew (1976),

McHone and Fyffe (2014), McHone et al. (2014), Merle et al. (2014), Murphy et al. (2011),

O'Loughlin ( 1977), Papezik and Barr (1981), Papezik and Hodych (1980), Papezik et al.

(1988), Pe-Piper and Piper (1999), Pe-Piper et al. (1992), Sinha (1970), Wark (1980), and

Wark and Clarke (1980).

Figure 9. Trace element data (in ppm) from the Ashfield Formation and Fundy Basin flows and dykes plotted against $\mathrm{MgO}$ (weight \%), recalculated on a volatile-free basis. Chemical data from the Fundy Basin flows and dykes were compiled mainly from sources cited in Figure 8.

Figure 10. Chondrite-normalized rare-earth element (REE) patterns for the basaltic samples from the Ashfield Formation (Table 2) compared to Fundy Basin flows and dykes (data from Dostal and Dupuy 1984, Dostal and Greenough 1992, Murphy et al. 2011). Chondritenormalizing values are from Sun and McDonough (1989).

Figure 11. Binary plots used to illustrate the chemical affinity of basaltic samples from the Ashfield Formation to Fundy Basin flows and dykes (a) $\mathrm{SiO}_{2}$ versus total alkalis classification diagram from LeBas et al. (1986) with the alkaline/subalkaline dividing line from Irvine and Baragar (1971). The dashed CAMP field is based on samples from Bertrand et al. (1982), McHone (2000), and Marzoli et al. (2004). (b) $\mathrm{The} \mathrm{Zr} / \mathrm{TiO}_{2}$ versus $\mathrm{Nb} / \mathrm{Y}$ classification diagram from Winchester and Floyd (1976) as modified by Pearce (1996). The 
chemical data from the Fundy Basin flows and dykes were compiled mainly from sources cited in Figure 8.

Figure 12. Diagrams to illustrate chemical affinity and tectonic setting of basaltic samples from the Ashfield Formation and compare them to data for the Fundy Basin flows and dykes. (a) AFM diagram with the tholeiitic-calc-alkalic dividing line from Irvine and Baragar (1971). (b) $\mathrm{Plot}$ of $\mathrm{TiO}_{2}$ versus $\mathrm{FeO}^{\mathrm{T}} / \mathrm{MgO}$. The high- and low-Ti continental flood basalt fields are after Albarède (1992). Chemical data from the Fundy Basin flows and dykes were compiled mainly from sources cited in Figure 8.

Figure 13. (a) $\mathrm{Zr} / \mathrm{Y}$ versus $\mathrm{Zr}$ diagram with fields after Pearce and Cann (1973). (b) La/Yb versus $\mathrm{TiO}_{2}$ showing the chemical groups of Mesozoic CAMP basalts from the eastern margin of North America with fields after Merle et al. (2014). Chemical data from the Fundy Basin flows and dykes were compiled mainly from sources cited in Figure 8.

Figure 14. Probability diagram for ${ }^{40} \mathrm{Ar}-{ }^{39} \mathrm{Ar}, \mathrm{K}-\mathrm{Ar}$, and $\mathrm{U}-\mathrm{Pb}$ (zircon) ages from the Central Atlantic Magmatic Province. Age data were compiled mainly from Armstrong and Besancon (1970), Baksi (2007), Blackburn et al. (2013), Dallmeyer (1975), Dunn (1994), Dunn et al. (1998), Dunning and Hodych (1990), Hames et al. (2000), Hodych and Dunning (1992), Hodych and Hayatsu (1988), Jourdan et al. (2009), Kontak and Archibald (2003), Marzoli et al. (2011), McHone et al. (2014), Nomade et al. (2007), Schoene et al. (2006), Schoene et al. (2010), Seiderman et al. (1984), Stringer and Burke (1985), Weston Geophysical (1977), and Whalen et al. (2015). 


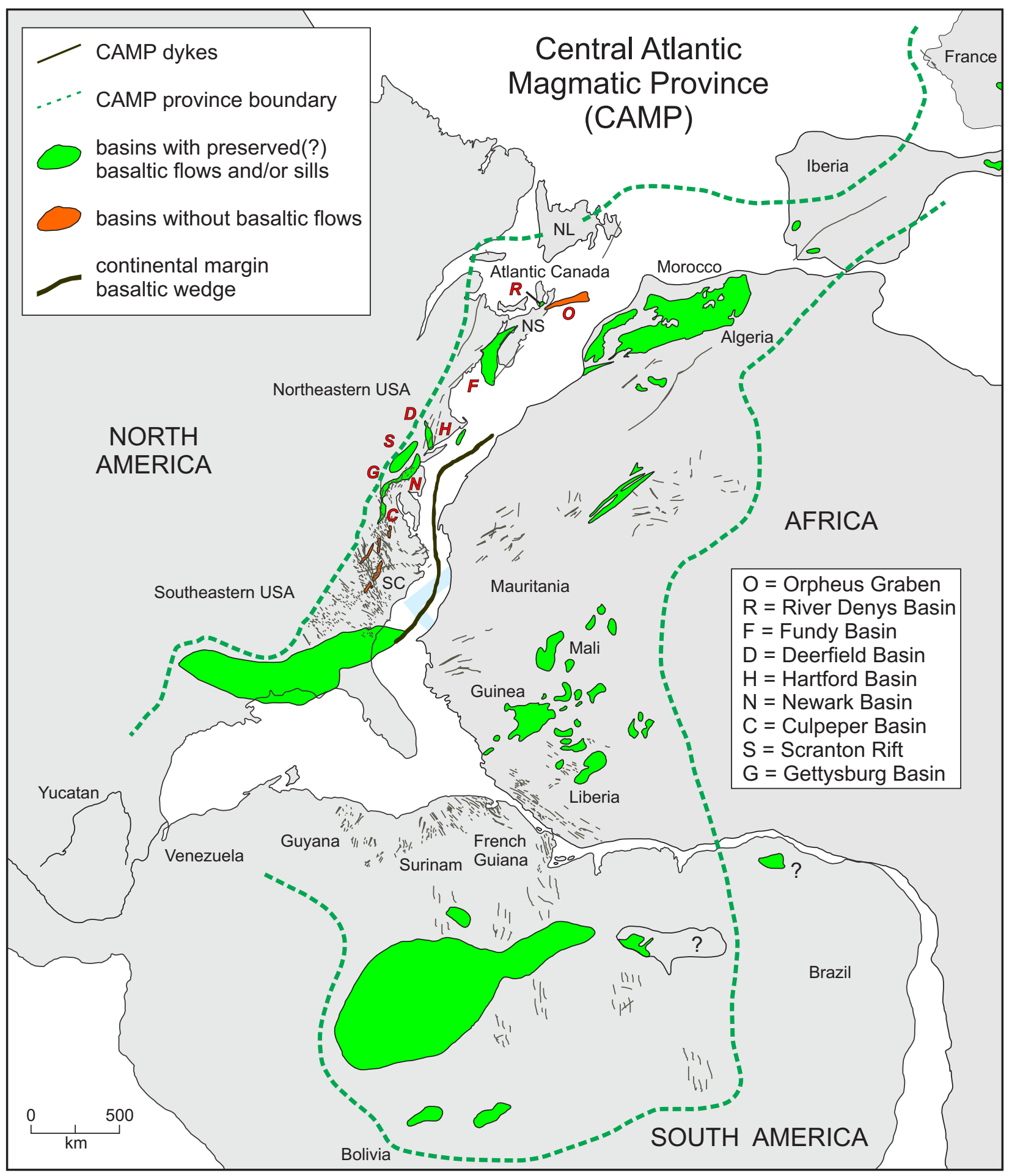

Fig. 1. White et al. 


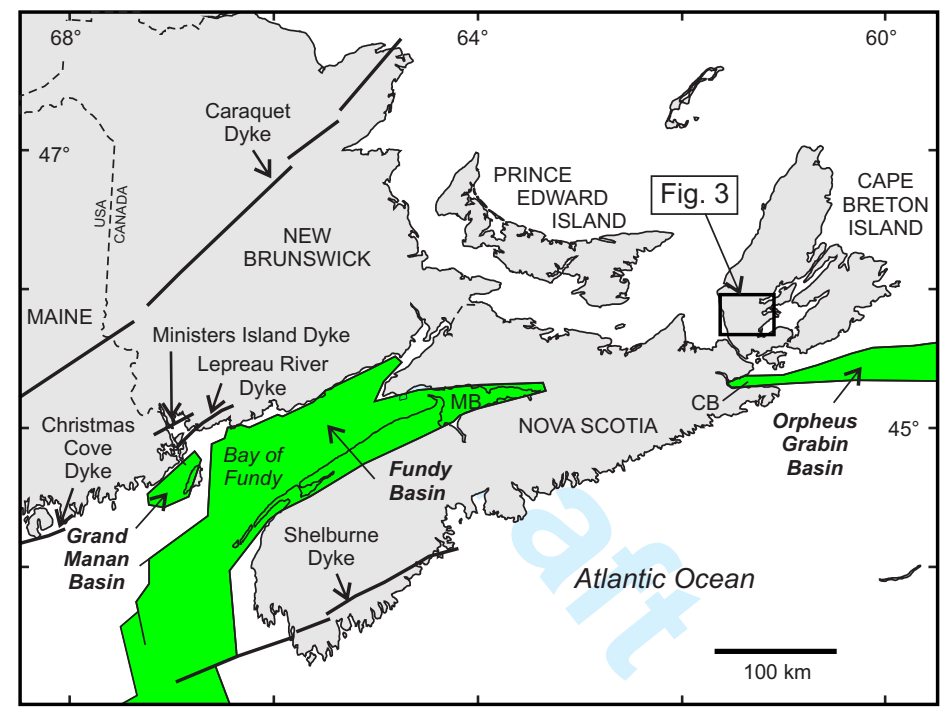

Fig. 2. White et al. 


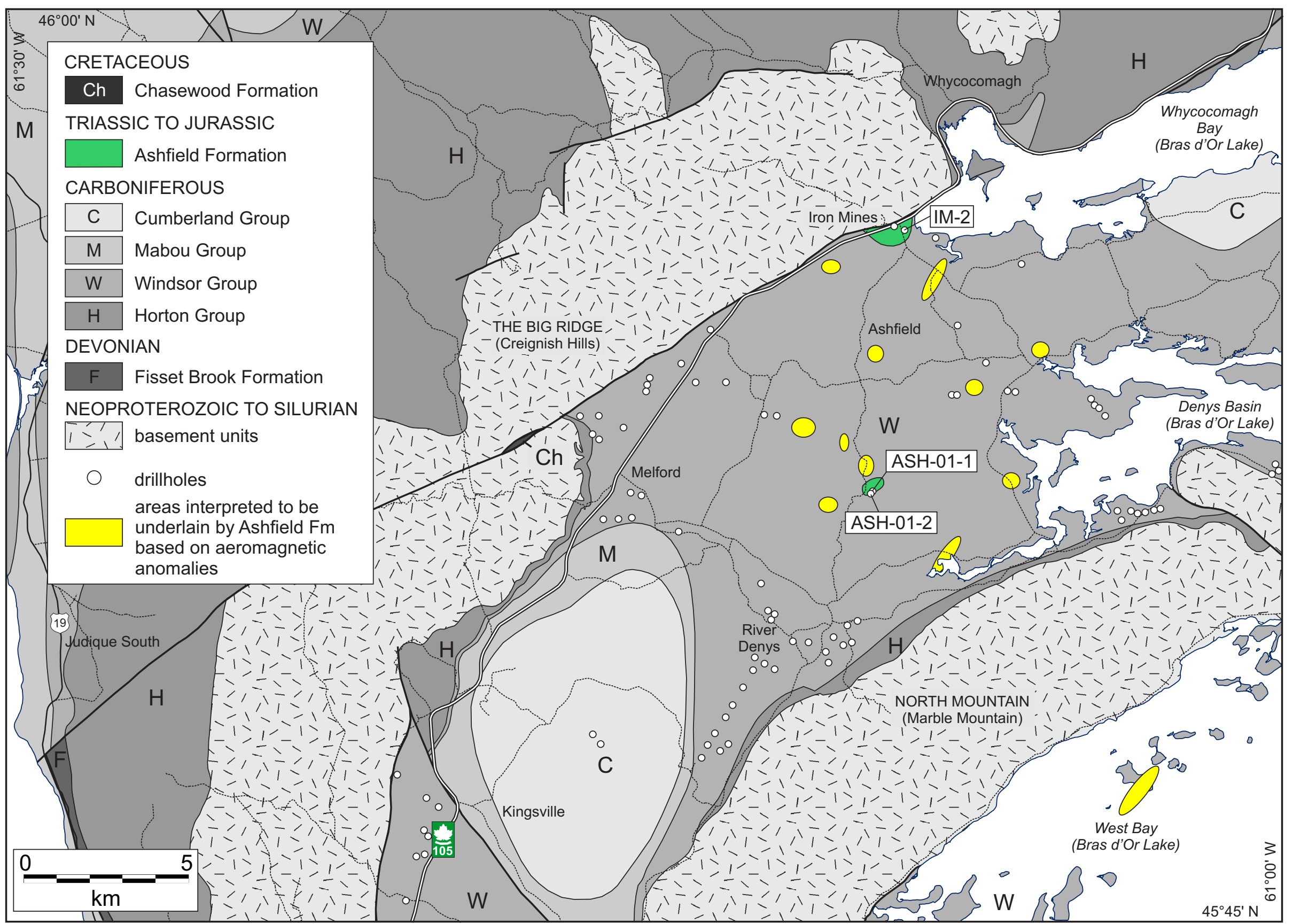

Fig. 3. White et al. 


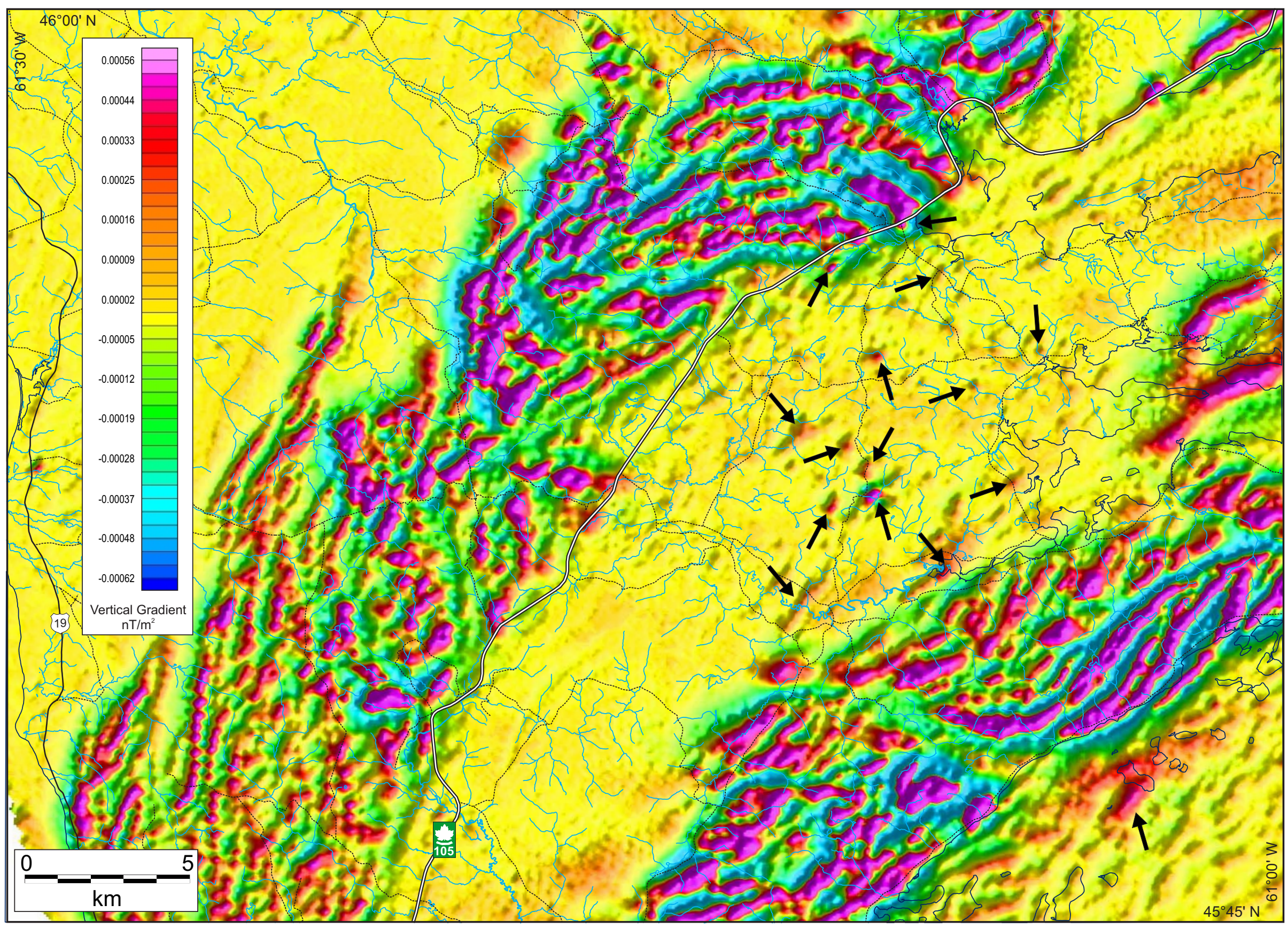

Fig. 4. White et al. 


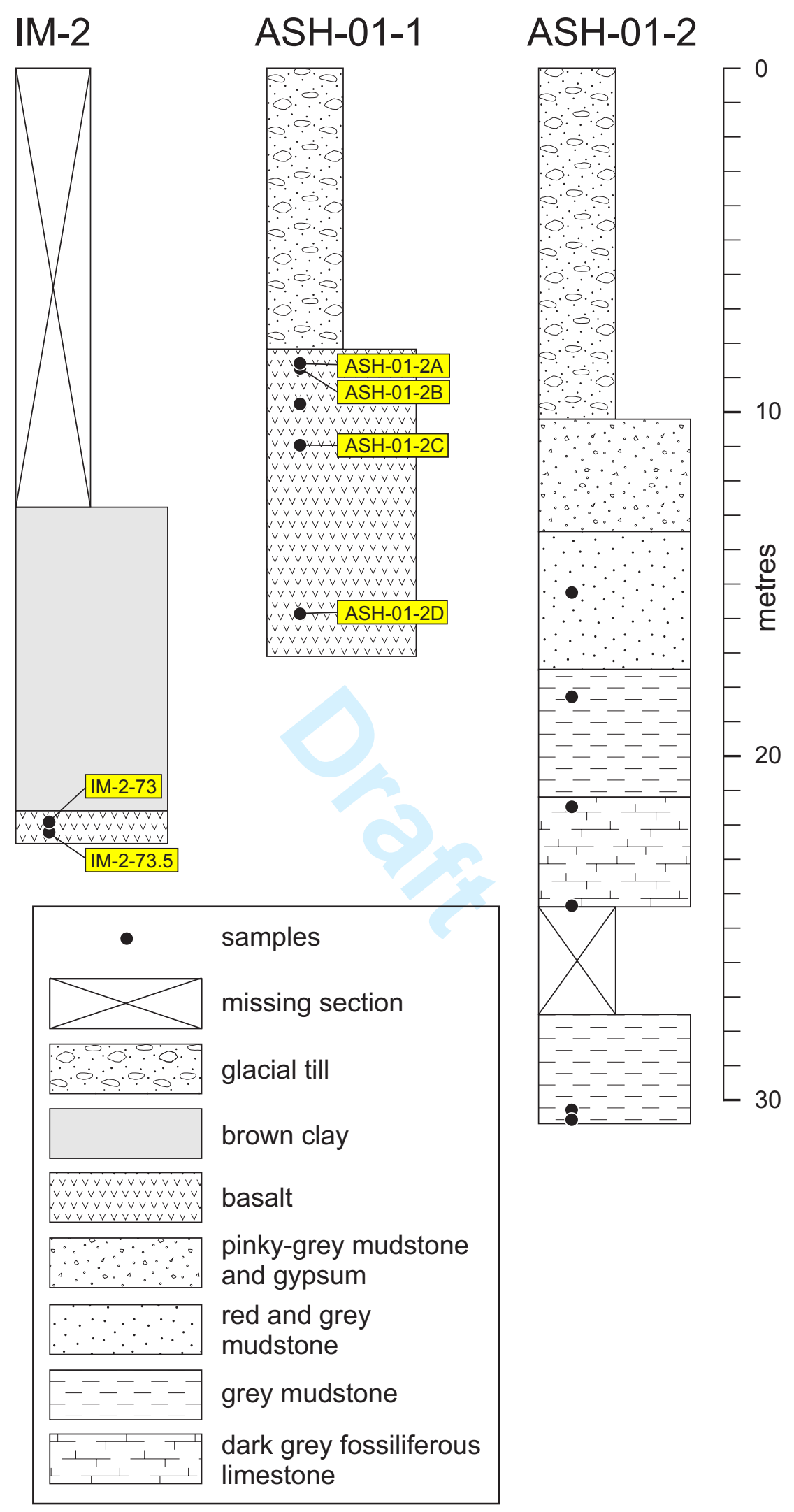

Fig. 5. White et al. 

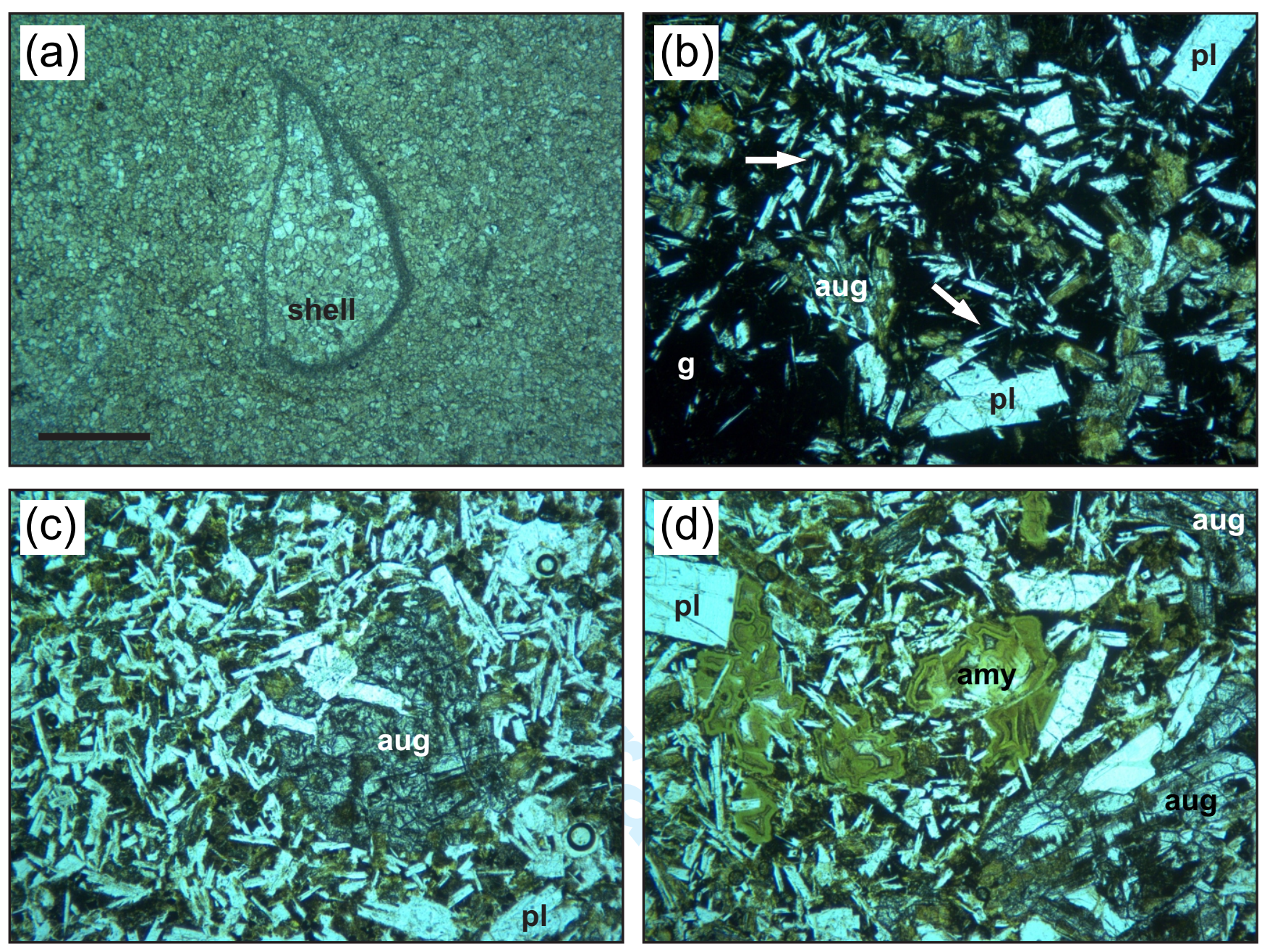

Fig. 6. White et al. 


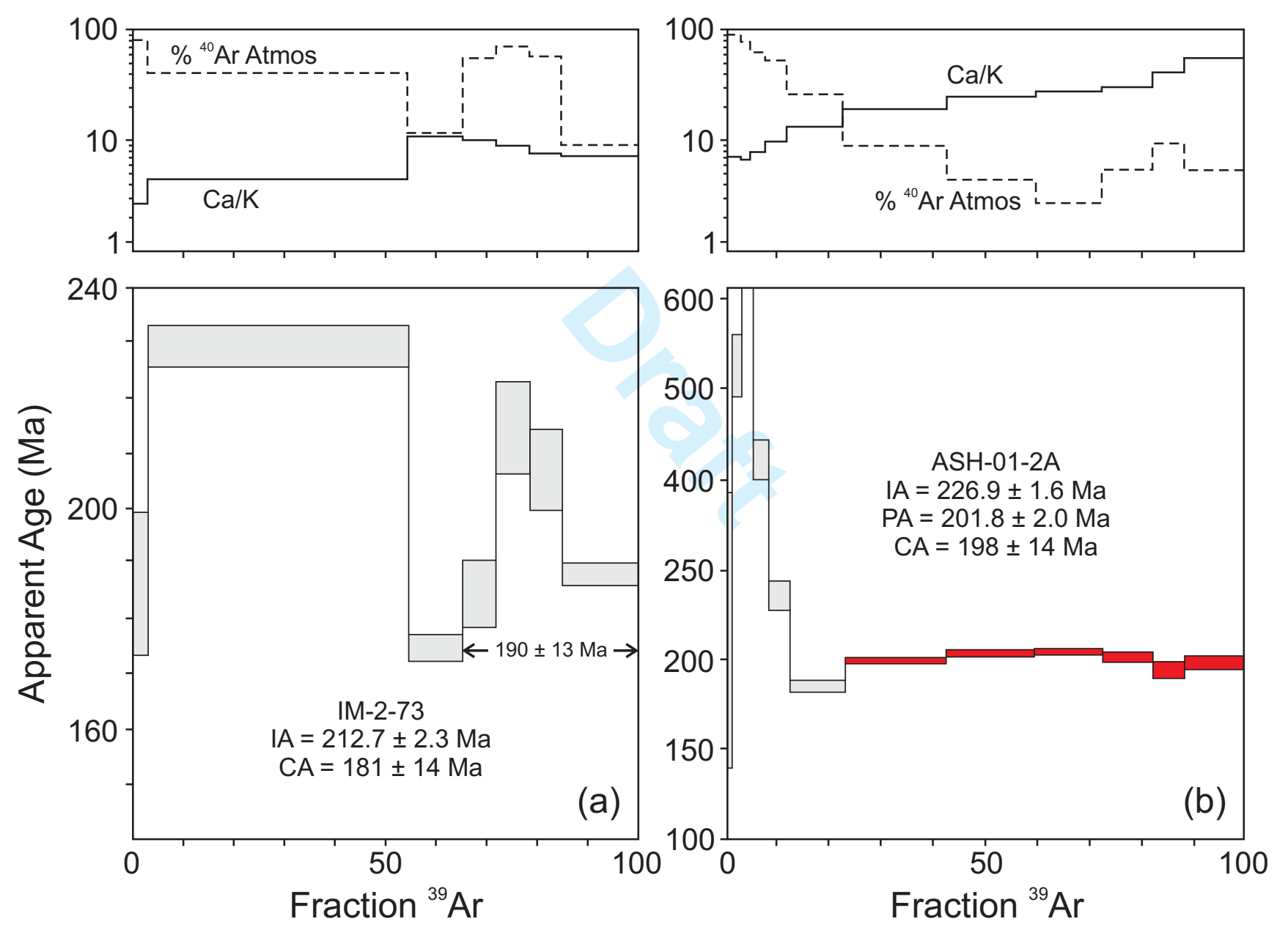

Fig. 7. White et al. 

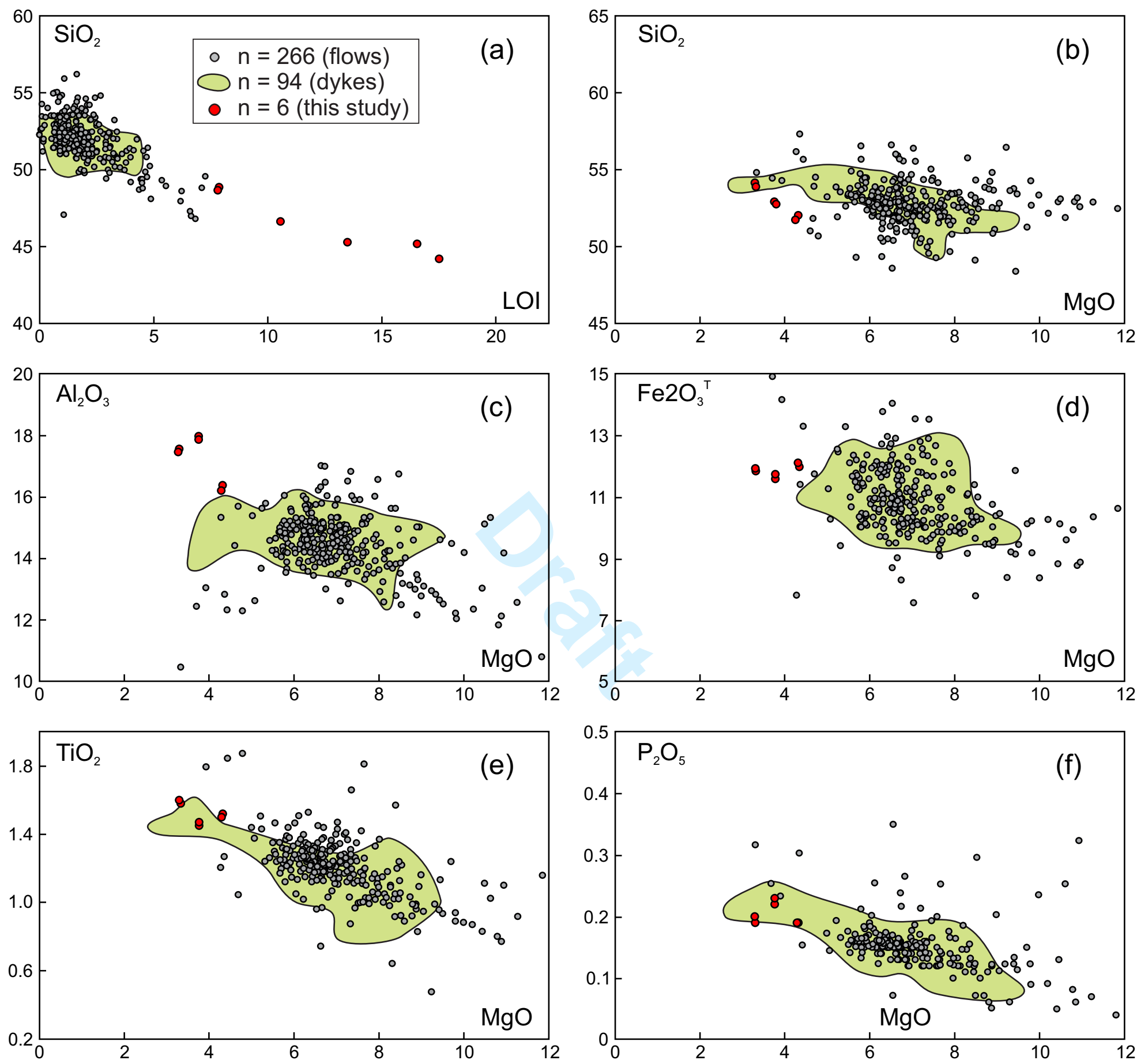

Fig. 8. White et al. 

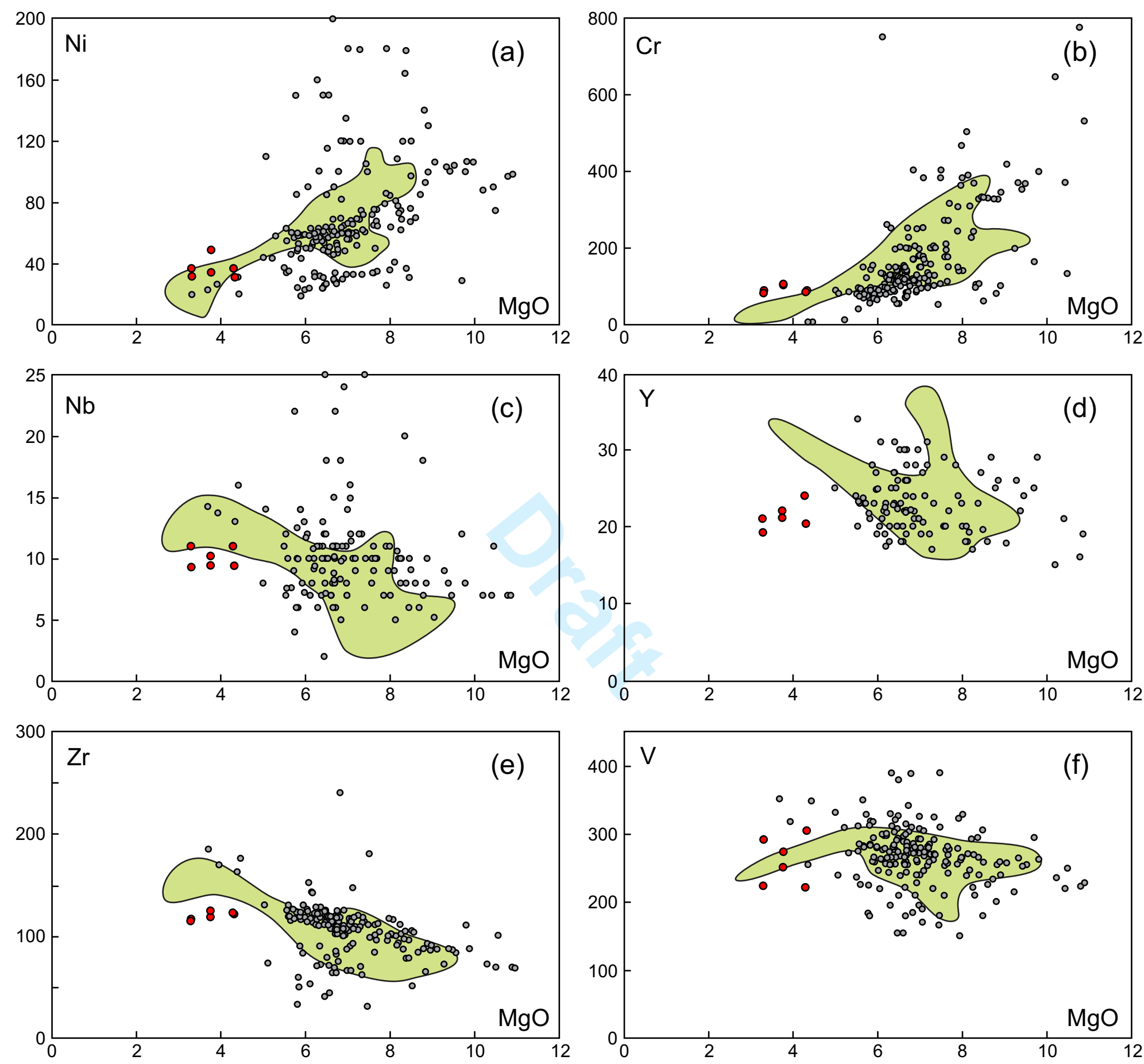

Fig. 9. White et al. 


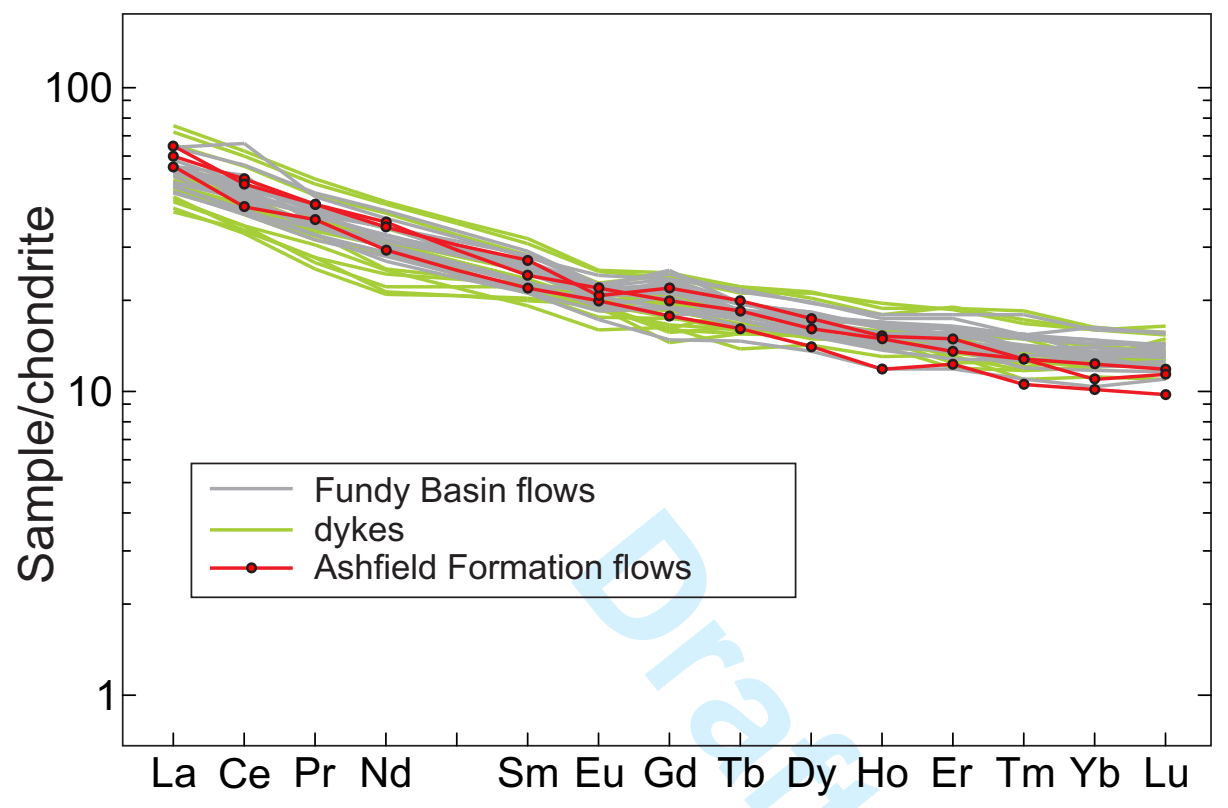

Fig. 10. White et al. 

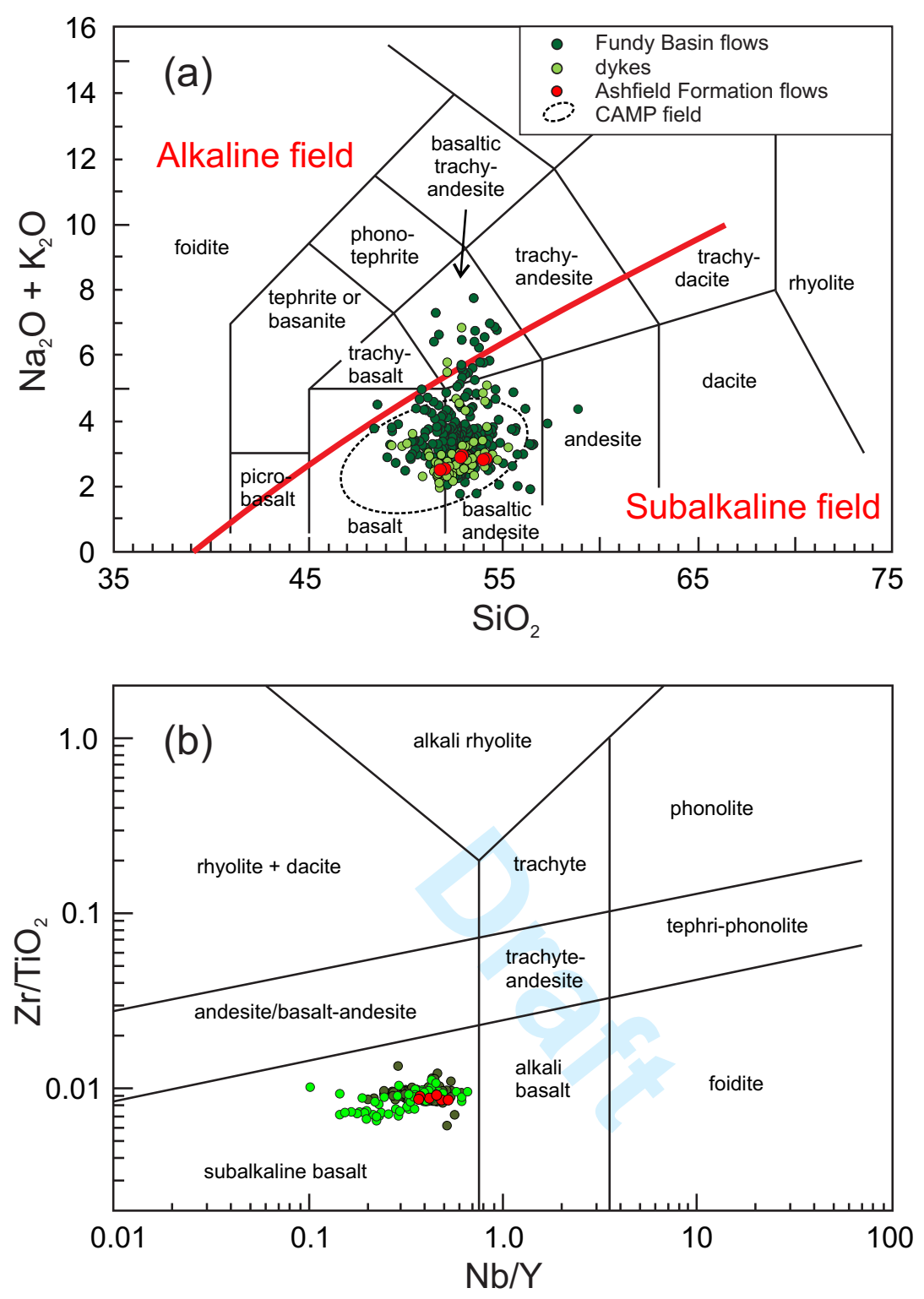

Fig. 11. White et al. 

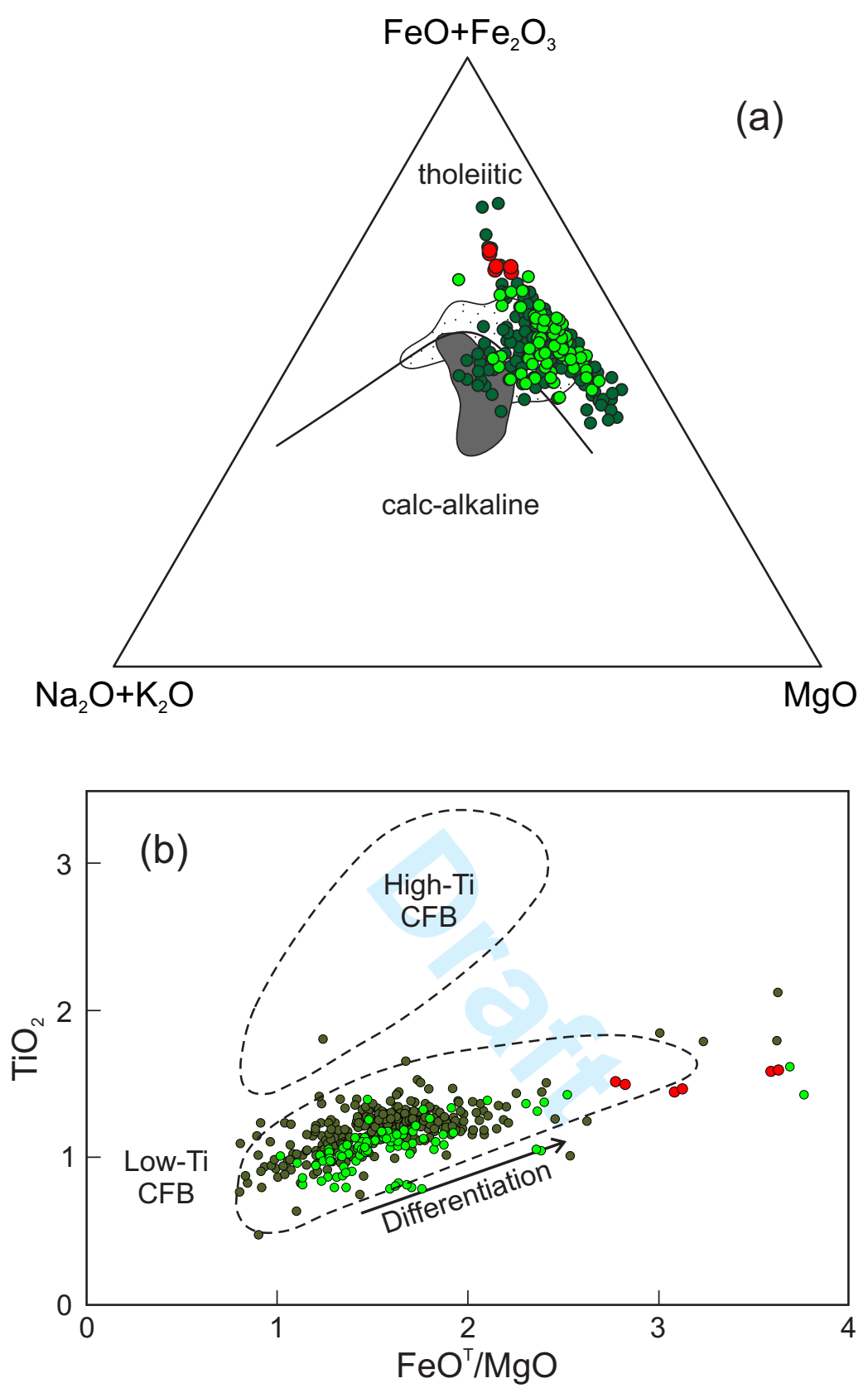

Fig. 12. White et al. 

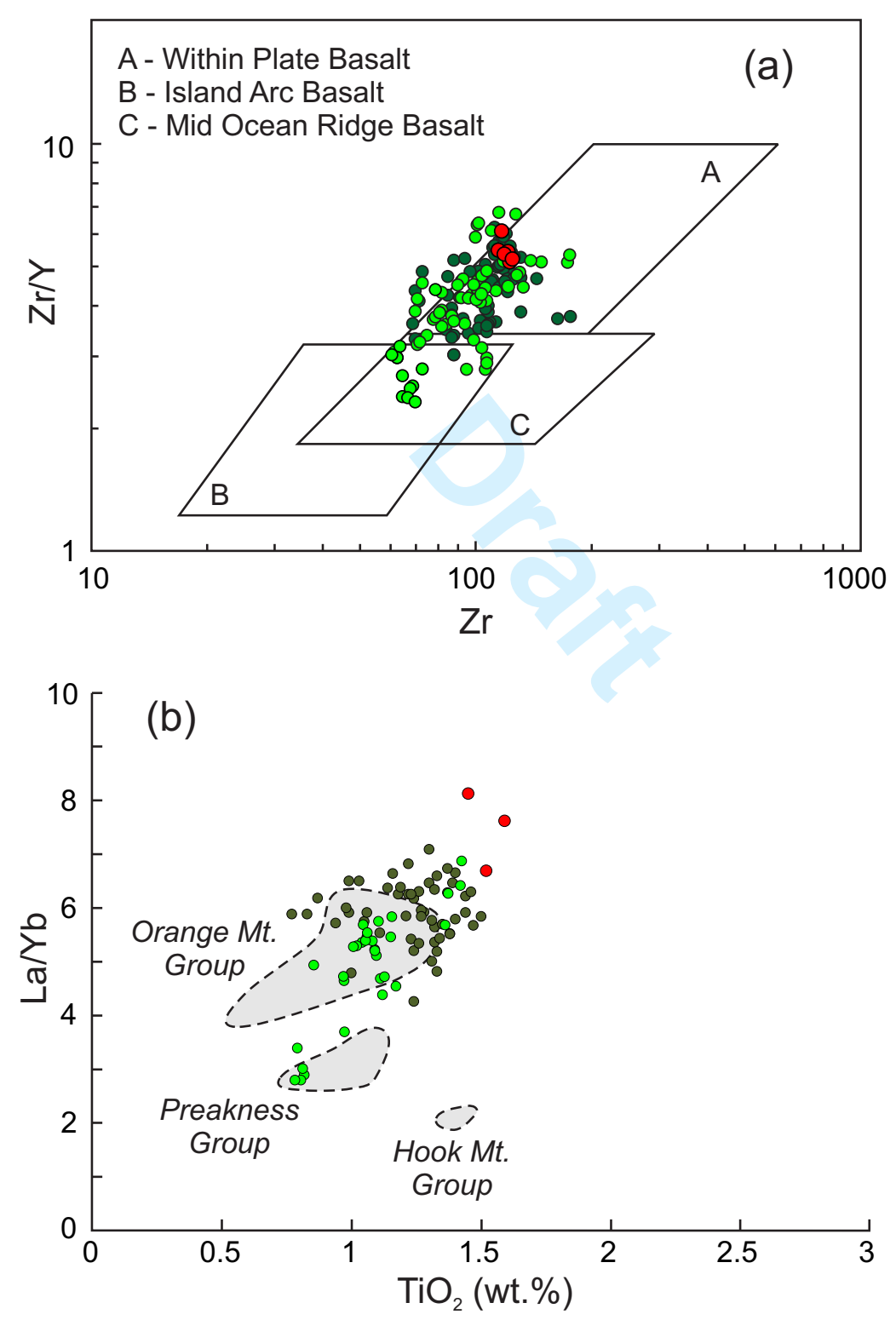

Fig. 13. White et al. 


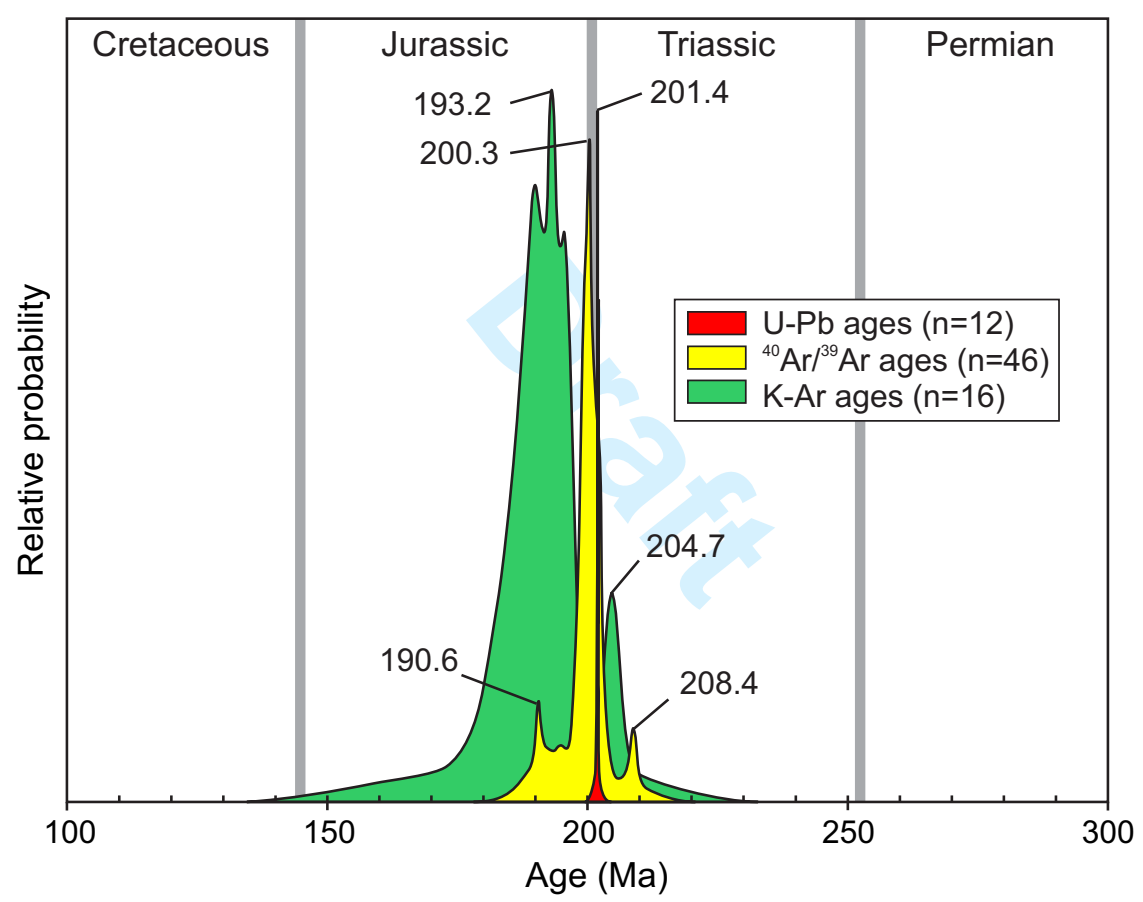

Fig. 14. White et al. 
Table 1. Results of ${ }^{40} \mathrm{Ar} /{ }^{39} \mathrm{Ar}$ analyses for whole rock samples of basalt in the Ashfield Formation.

\begin{tabular}{|c|c|c|c|c|c|c|c|c|c|c|c|c|c|c|c|c|}
\hline Step & $\begin{array}{l}\text { Power } \\
\text { (W) }\end{array}$ & ${ }^{40} \mathrm{Ar} /{ }^{39} \mathrm{Ar}$ & $\begin{array}{c} \pm \\
(1 \sigma)\end{array}$ & ${ }^{38} \mathrm{Ar} /{ }^{39} \mathrm{Ar}$ & $\begin{array}{c} \pm \\
(1 \sigma)\end{array}$ & ${ }^{37} \mathrm{Ar} /{ }^{39} \mathrm{Ar}$ & $\begin{array}{c} \pm \\
(1 \%)\end{array}$ & ${ }^{36} \mathrm{Ar} /{ }^{39} \mathrm{Ar}$ & $\begin{array}{c} \pm \\
(1 \%)\end{array}$ & ${ }^{40} \mathrm{Ar} * /{ }^{39} \operatorname{Ar}(\mathrm{K})$ & $\begin{array}{c} \pm \\
(1 \%)\end{array}$ & $\mathrm{Ca} / \mathrm{K}$ & $\begin{array}{l}{ }^{40} \mathrm{Ar}^{*} \\
(\%)\end{array}$ & $\begin{array}{c}\text { Cumulative }{ }^{39} \mathrm{Ar} \\
(\%)\end{array}$ & $\begin{array}{l}\text { Age } \\
(\mathrm{Ma})\end{array}$ & $\begin{array}{c} \pm \\
(1 \%)\end{array}$ \\
\hline \multicolumn{17}{|c|}{ Sample: IM-2-73, J value $=0.010921 \pm 0.000019(1 \%)$} \\
\hline 1 & 0.3 & 44.2202 & 0.405 & 0.138 & 0.002 & 1.378 & 0.024 & 0.116 & 0.002 & 9.995 & 0.407 & 2.52 & 22.6 & 3.11 & 187.16 & 7.25 \\
\hline 2 & 0.5 & 21.1924 & 0.099 & 0.046 & 0.001 & 2.413 & 0.016 & 0.030 & 0.000 & 12.575 & 0.114 & 4.42 & 59.2 & 54.35 & 232.48 & 1.98 \\
\hline 3 & 0.8 & 10.5363 & 0.020 & 0.030 & 0.000 & 5.956 & 0.023 & 0.006 & 0.000 & 9.314 & 0.063 & 10.94 & 88.0 & 65.36 & 175.00 & 1.13 \\
\hline 4 & 1 & 22.1389 & 0.094 & 0.069 & 0.001 & 5.427 & 0.034 & 0.043 & 0.001 & 9.891 & 0.171 & 9.97 & 44.5 & 71.72 & 185.30 & 3.04 \\
\hline 5 & 1.3 & 37.5309 & 0.179 & 0.101 & 0.001 & 4.755 & 0.030 & 0.089 & 0.001 & 11.680 & 0.239 & 8.73 & 31.0 & 78.62 & 216.89 & 4.18 \\
\hline 6 & 1.5 & 26.0655 & 0.102 & 0.077 & 0.001 & 4.144 & 0.028 & 0.051 & 0.001 & 11.228 & 0.202 & 7.61 & 42.9 & 84.95 & 208.96 & 3.55 \\
\hline 7 & 2 & 11.0568 & 0.031 & 0.045 & 0.001 & 3.914 & 0.017 & 0.004 & 0.000 & 10.066 & 0.059 & 7.18 & 90.8 & 100.00 & 188.43 & 1.05 \\
\hline
\end{tabular}

Last 4 steps age $=190 \pm 13(2 \sigma) ; 34.6 \%$ of gas

Integrated age $=212.70 \pm 2.26\left(2 \sigma^{\circ}\right) ; \pm 2.41\left(2 \sigma^{\circ}\right)$ with $\mathrm{J}$ error

Correlation age $=181 \pm 14(2 \circ), \operatorname{MSWD}=27$

Sample: ASH-01-2A, J value $=0.01094 \pm 0.000023(10)$

$\begin{array}{cccccccccccccccccc}1 & 0.3 & 164.954 & 3.117 & 0.196 & 0.010 & 3.477 & 0.122 & 0.520 & 0.012 & 11.661 & 2.205 & 6.38 & 7.1 & 0.60 & 216.56 & 38.58 \\ 2 & 0.5 & 219.126 & 1.870 & 0.169 & 0.003 & 3.508 & 0.050 & 0.639 & 0.007 & 30.720 & 1.214 & 6.44 & 14.0 & 2.73 & 522.59 & 17.93 \\ 3 & 0.7 & 144.181 & 1.310 & 0.101 & 0.003 & 3.338 & 0.049 & 0.354 & 0.004 & 39.959 & 0.930 & 6.12 & 27.6 & 5.08 & 654.12 & 12.76 \\ 4 & 0.8 & 57.767 & 0.374 & 0.049 & 0.002 & 4.107 & 0.049 & 0.117 & 0.002 & 23.706 & 0.473 & 7.54 & 40.9 & 7.76 & 415.90 & 7.41 \\ 5 & 1.0 & 25.412 & 0.106 & 0.028 & 0.001 & 5.123 & 0.044 & 0.044 & 0.001 & 12.784 & 0.220 & 9.41 & 50.1 & 11.91 & 236.11 & 3.81 \\ 6 & 1.5 & 13.149 & 0.032 & 0.018 & 0.000 & 7.235 & 0.029 & 0.013 & 0.000 & 9.911 & 0.091 & 13.31 & 75.0 & 22.51 & 185.66 & 1.62 \\ 7 & 2.0 & 11.696 & 0.019 & 0.017 & 0.000 & 10.007 & 0.027 & 0.006 & 0.000 & 10.709 & 0.052 & 18.44 & 90.9 & 42.52 & 199.82 & 0.91 \\ 8 & 2.5 & 11.363 & 0.019 & 0.019 & 0.000 & 12.786 & 0.033 & 0.005 & 0.000 & 10.947 & 0.056 & 23.61 & 95.5 & 59.62 & 204.02 & 0.98 \\ 9 & 3.0 & 11.188 & 0.021 & 0.028 & 0.000 & 14.236 & 0.041 & 0.005 & 0.000 & 10.976 & 0.065 & 26.32 & 97.1 & 72.71 & 204.53 & 1.15 \\ 10 & 4.0 & 11.334 & 0.026 & 0.059 & 0.001 & 15.599 & 0.048 & 0.006 & 0.000 & 10.828 & 0.084 & 28.86 & 94.5 & 82.33 & 201.91 & 1.49 \\ 11 & 6.0 & 11.341 & 0.032 & 0.158 & 0.001 & 20.914 & 0.075 & 0.009 & 0.000 & 10.439 & 0.137 & 38.85 & 90.7 & 88.47 & 195.04 & 2.43 \\ 12 & 7.0 & 11.054 & 0.026 & 0.041 & 0.001 & 27.568 & 0.077 & 0.010 & 0.000 & 10.655 & 0.107 & 51.45 & 94.5 & 100.00 & 198.86 & 1.90\end{array}$

Plateau age $=201.8 \pm 2.0(2 \sigma) ; \pm 1.35$ with $\mathrm{J} ; \mathrm{MSWD}=1.30 ; 77.5 \%{ }^{39} \mathrm{Ar}$

Integrated age $=226.88 \pm 1.61(2 \circ) ; \pm 1.85\left(2 \sigma^{\circ}\right)$ with J error

Correlation age $=198 \pm 14(2 \circ)$, MSWD $=67$ 
Table 2. Whole rock analyses from basalt in the Ashfield Formation.

\begin{tabular}{|c|c|c|c|c|c|c|}
\hline Sample & $\begin{array}{c}\text { IM-02- } \\
73\end{array}$ & $\begin{array}{c}\text { IM-02- } \\
73.5\end{array}$ & $\begin{array}{c}\mathrm{ASH}-01- \\
2 \mathrm{~A}\end{array}$ & $\begin{array}{c}\text { ASH-01- } \\
2 \mathrm{~B}\end{array}$ & $\begin{array}{c}\mathrm{ASH}-01- \\
2 \mathrm{C}\end{array}$ & $\begin{array}{c}\text { ASH-01- } \\
2 \mathrm{D}\end{array}$ \\
\hline $\mathrm{SiO}_{2}$ (wt. \%) & 45.16 & 44.19 & 48.84 & 46.61 & 45.27 & 48.79 \\
\hline $\mathrm{TiO}_{2}$ & 1.33 & 1.31 & 1.34 & 1.36 & 1.31 & 1.36 \\
\hline $\mathrm{Al}_{2} \mathrm{O}_{3}$ & 14.64 & 14.36 & 16.60 & 14.67 & 14.17 & 16.50 \\
\hline $\mathrm{Fe}_{2} \mathrm{O}_{3}{ }^{\mathrm{T}}$ & 9.88 & 9.77 & 10.71 & 10.74 & 10.60 & 10.85 \\
\hline $\mathrm{MnO}$ & 0.10 & 0.10 & 0.07 & 0.11 & 0.11 & 0.07 \\
\hline $\mathrm{MgO}$ & 2.75 & 2.69 & 3.47 & 3.87 & 3.75 & 3.47 \\
\hline $\mathrm{CaO}$ & 7.01 & 6.97 & 8.36 & 9.79 & 9.87 & 8.44 \\
\hline $\mathrm{Na}_{2} \mathrm{O}$ & 1.86 & 1.81 & 2.20 & 1.91 & 1.81 & 2.15 \\
\hline $\mathrm{K}_{2} \mathrm{O}$ & 0.50 & 0.48 & 0.51 & 0.35 & 0.37 & 0.50 \\
\hline $\mathrm{P}_{2} \mathrm{O}_{5}$ & 0.16 & 0.16 & 0.20 & 0.17 & 0.17 & 0.21 \\
\hline $\mathrm{Cr}_{2} \mathrm{O}_{3}$ & 0.01 & 0.01 & 0.02 & 0.01 & 0.01 & 0.02 \\
\hline LOI & 16.55 & 17.52 & 7.87 & 10.56 & 13.50 & 7.79 \\
\hline Total & 99.96 & 99.38 & 100.19 & 100.16 & 100.95 & 100.15 \\
\hline $\mathrm{Ba}(\mathrm{ppm})$ & 86 & 147 & 105 & 133 & 162 & 155 \\
\hline $\mathrm{Rb}$ & 7 & 11 & 10 & 5 & 9 & 13 \\
\hline $\mathrm{Sr}$ & 194 & 187 & 249 & 289 & 271 & 245 \\
\hline $\mathrm{Y}$ & 19.2 & 21 & 22.2 & 22.4 & 24 & 24 \\
\hline $\mathrm{Zr}$ & 117 & 115 & 119 & 122 & 123 & 125 \\
\hline $\mathrm{Nb}$ & 9.3 & 11 & 8.2 & 9.4 & 11 & 9 \\
\hline Th & 3 & & 3.2 & 3.7 & & \\
\hline $\mathrm{Pb}$ & 3.4 & 1.5 & 3.6 & 4.2 & 3 & 4 \\
\hline $\mathrm{Ga}$ & 16.5 & 15 & 17 & 16.5 & 15 & 19 \\
\hline $\mathrm{Zn}$ & 45 & 64 & 108 & 81 & 103 & 130 \\
\hline $\mathrm{Cu}$ & 49.4 & 86 & 69.5 & 56.3 & 84 & 83 \\
\hline $\mathrm{Ni}$ & 31.7 & 37 & 34.4 & 31.2 & 37 & 49 \\
\hline $\mathrm{V}$ & 292 & 224 & 275 & 305 & 222 & 251 \\
\hline $\mathrm{Cr}$ & 102 & 82 & 95 & 113 & 85 & 106 \\
\hline $\mathrm{U}$ & 1.5 & & 1.1 & 1.3 & & \\
\hline $\mathrm{Co}$ & 34.5 & 46 & 45.1 & 49 & 62 & 56 \\
\hline $\mathrm{Nd}$ & 13.6 & 18 & 16.8 & 16.2 & 22 & 21 \\
\hline $\mathrm{La}$ & 13.1 & 18 & 15.1 & 14.1 & 20 & 23 \\
\hline $\mathrm{Cs}$ & 0.2 & & 0.6 & 0.2 & & \\
\hline Hf & 3.1 & & 3.4 & 3.4 & & \\
\hline $\mathrm{Ce}$ & 25 & & 29.3 & 30.4 & & \\
\hline $\mathrm{Sm}$ & 3.36 & & 3.71 & 4.14 & & \\
\hline $\mathrm{Eu}$ & 1.15 & & 1.28 & 1.21 & & \\
\hline $\mathrm{Tb}$ & 0.6 & & 0.69 & 0.74 & & \\
\hline $\mathrm{Yb}$ & 1.72 & & 1.86 & 2.11 & & \\
\hline $\mathrm{Lu}$ & 0.25 & & 0.29 & 0.3 & & \\
\hline Mo & 0.05 & & 0.2 & 0.1 & & \\
\hline $\mathrm{Ta}$ & 0.7 & & 0.6 & 0.6 & & \\
\hline $\mathrm{Se}$ & 0.25 & & 0.25 & 0.25 & & \\
\hline Gd & 3.68 & & 4.13 & 4.48 & & \\
\hline $\operatorname{Pr}$ & 3.48 & & 3.94 & 3.91 & & \\
\hline Dy & 3.56 & & 4.13 & 4.41 & & \\
\hline Ho & 0.67 & & 0.85 & 0.87 & & \\
\hline $\mathrm{Er}$ & 2.04 & & 2.26 & 2.48 & & \\
\hline $\mathrm{Tm}$ & 0.27 & & 0.33 & 0.33 & & \\
\hline W & 22.9 & & 54.2 & 38.5 & & \\
\hline $\mathrm{Tl}$ & 0.05 & & 0.05 & 0.05 & & \\
\hline $\mathrm{Au}(\mathrm{ppb})$ & 0.25 & & 11.4 & 7.3 & & \\
\hline
\end{tabular}

